2012

\title{
Social Enterprise and Christian School Finance: Receptivity of ACSI Christian School Leaders in Mid-America
}

Eric D. Schroeder

Cedarville University

Follow this and additional works at: http://digitalcommons.cedarville.edu/education_theses

Part of the Elementary and Middle and Secondary Education Administration Commons, Finance and Financial Management Commons, Other Education Commons, and the Other Educational Administration and Supervision Commons

\section{Recommended Citation}

Schroeder, Eric D., "Social Enterprise and Christian School Finance: Receptivity of ACSI Christian School Leaders in Mid-America" (2012). Master of Education Research Theses. 55.

http://digitalcommons.cedarville.edu/education_theses/55 
SOCIAL ENTERPRISE AND CHRISTIAN SCHOOL FINANCE:

RECEPTIVITY OF ACSI CHRISTIAN SCHOOL LEADERS IN MID-AMERICA

A thesis submitted in partial fulfillment

of the requirements for the degree of

Masters of Education

By

\section{ERIC DOUGLAS SCHROEDER}

B.A. Language Arts Education - Integrated, Cedarville University, 2004

2012

Cedarville University 


\begin{abstract}
Schroeder, Eric D. M.Ed., Education Department, Cedarville University, 2012. Social Enterprise and Christian School Finance: Receptivity of ACSI Christian School Leaders in Mid-America.
\end{abstract}

This pioneering study draws on literature from both the educational and the nonprofit sectors to integrate the concept of social enterprise with the financial challenges faced by Christian schools. It then explores the receptivity of administrators and board chairmen of Association of Christian Schools International affiliated schools in the MidAmerica region to social enterprise based fund raising practices. Findings show that while school leaders are cautious overall, interest varies widely with some school leaders being very receptive and other very opposed to these approaches. Analysis of specific subcategories indicates that school leaders have a greater interest in pursuing opportunities that connect with their target audience, promote products or services indirectly or promote through traditional forms of fundraising including students selling products outside of school. Results were consistent between administrators and board chairmen with significant variance only occurring in the development of curriculum and training programs for an outside audience. 


\section{TABLE OF CONTENTS}

\section{Page}

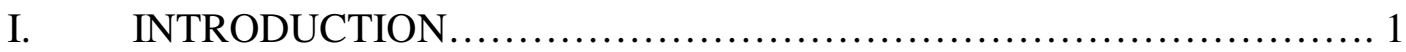

Definition of Terms.............................................4

Statement of Issue..........................................6

Scope of the Study and Delimitations..............................8

Significance of the Study....................................

Methods........................................................11

II. REVIEW OF THE LITERATURE................................... 14

Historical Background...........................................14

Modern Struggles in School Finance................................15

Facing the Challenge of Financing Private Schools...................23

Social Enterprise.............................................28

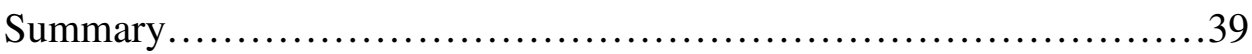

III. METHODOLOGY ...............................................41

Introduction to the Method.......................................41

Rationale for the Method........................................41

Population of the Study.........................................43

Procedure....................................................44

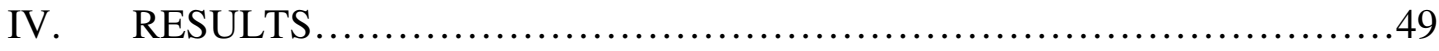

Introduction.................................................. 49

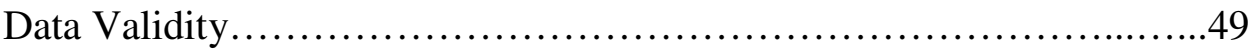


General Trends.................................................51

Item Analysis.....................................................53

Variance by Position Held by Responder.............................76

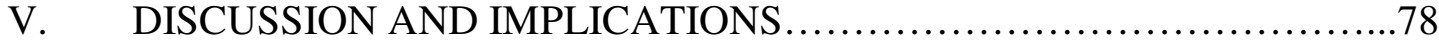

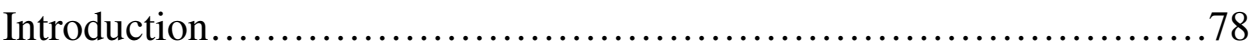

Interpretation and Application......................................78

Biblical Integration............................................... 84

Relation of the Results to Literature $\ldots \ldots \ldots \ldots \ldots \ldots \ldots \ldots \ldots \ldots \ldots \ldots . \ldots 7$

Strengths of the Study..........................................91

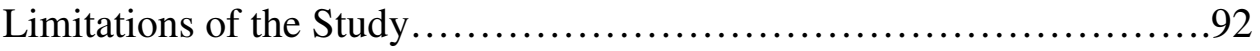

Suggestions for Further Research..................................94

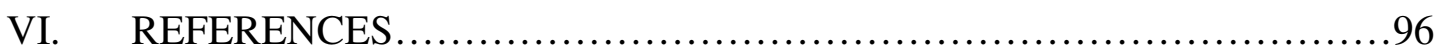

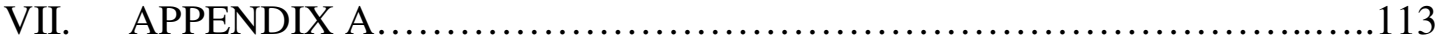




\section{LIST OF TABLES}

Table

Page

1. Overall current involvement......................................... 51

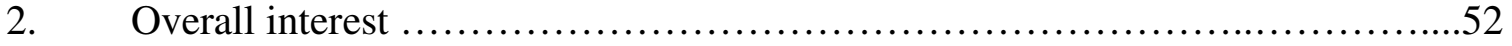

3. Overall expected board interest........................................53

4. Current sponsorships................................................54

5. Current exclusive agreements....................................................

6. Current incentive programs............................................56

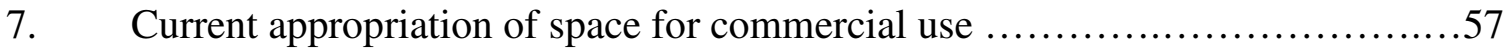

8. Current appropriation of space for non-commercial use $\ldots \ldots \ldots \ldots \ldots \ldots \ldots \ldots . .57$

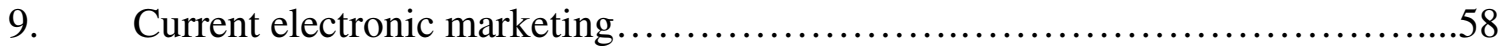

10. Current traditional fundraiser involvement...............................59

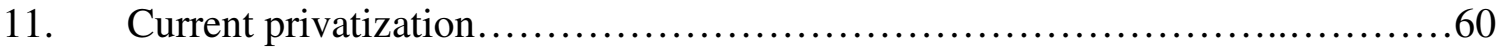

12. Current ongoing commercial venture...................................61

13. Current production and sale of materials.................................61

14. Current training opportunities.............................................61

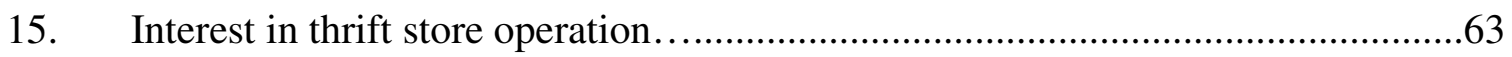

16. Interest in providing supplemental services ...........................................64

17. Interest in providing supplemental services to an outside audience....................65

18. Interest in providing classes to adults from local churches..............................66

19. Interest in providing classes to adults where no current involvement exists......67

20. Interest in creating curriculum for local churches or other Christian schools.......68 
21. Interest in creating curriculum for local churches or other Christian schools where no current involvement exists.............................69

22. Interest in renting space out during hours school is not in session...............70

23. Interest in renting space out during hours school is not in session where no current involvement exists........................................71

24. Interest in renting space out during hours school is in session..................72

25. Interest in renting space out during hours school is in session where no current involvement exists..........................................73

26. Interest in directly promoting products or services.........................74

27. Interest in corporate sponsorships................................... 75

28. Interest in corporate sponsorships where no current involvement exists.........76 


\section{Chapter 1: Introduction}

For many Americans, private schools have long been viewed as a desirable alternative to the public school system. In an opinion survey, 55 percent of respondents viewed independent schools as providing a better education than public schools (Looney, 2009). Similarly, in a 2011 survey conducted by Education Next, support for school vouchers to allow select students to attend private schools at public expense jumped $8 \%$ in one year (Howell 2011). In spite of this, only approximately 10\% of American parents send their children to private schools each year (Snyder \& Dillow, 2011). This gap begs the question of why American parents claim that they see a private school education as a better option for their children and yet rarely take advantage of it.

While the field of research investigating the answer to this question is strikingly narrow, the National Association of Independent Schools has written extensively on the topic. They propose that one of the key reasons more families do not avail themselves of the educational opportunities available in the private education sector is that for many parents, private schools are simply not affordable (Mitchell, 2009). Recent studies show that in spite of the economic downturn in the United States, the cost of providing a private school education has risen at rates far exceeding inflation (Snyder \& Dillow, 2011; Snyder, 1993). This leaves less and less families able to afford a private education. This is evidenced by the declining enrollment that has been observed in America's private schools, particularly in Catholic and other religious schools (Aud et al., 2011). Private schools are facing a very real financial challenge that only seems to be escalating. 
As the scope of this problem has becomes clearer, a few innovative Americans have begun to find creative ways to address the issue. One approach for students in America's urban centers is the Cristo Rey network. Started in 1996 by a group of Chicago Jesuits, this network of schools provides underprivileged youth with a private school education at a fraction of the cost of most other private schools. Their key funding mechanism is a program in which their students are paired into groups of four to share one entry level position at a local business (Couture, 2007). Each student spends five days per month in the corporate world with the same expectations as any other entry level employee. Companies provide funds to the school equivalent to what they would pay an entry level employee to do this work. Students participating in this program are more likely to graduate from high school and more likely to attend college than their peers coming from a similar socioeconomic background (Kearney, 2008). The Cristo Rey program provides a model for a new form of private school funding. The broad term given to this use of market forces to address social ills is social enterprise, and apart from the Cristo Rey network it has very little precedent in the private school world.

The term social enterprise has eluded definition for many scholars. In one publication alone eleven distinct definitions of the term social entrepreneurship are taken from the existing literature in the field and a twelfth definition is proposed (Massetti, 2008). Add to this the generally synonymous terms of social venture, social purpose business, hybrid business, double or triple bottom line business, and a string of others and it becomes clear that this field is one that has not yet established itself with a standard nomenclature. While the literature includes a broad variety of definitions for these terms, there are some basic commonalities. Social enterprises are at their core innovative 
organizations designed by social entrepreneurs that are established to employ practices from the business sector while focusing on meeting a social need (Trivedi \& Stokols, 2011).

Social enterprise has excited the imagination of many nonprofit leaders (Trexler, 2008). It allows nonprofits to potentially support a portion of their mission through earned revenue from either their existing clients or from outside sources (Popielarski \& Cotugna, 2010; Smith, Cronley, \& Barr, 2012). One well known example of this can be found in the Girl Scouts and the very tempting cookies they sell each year (Smith, Knapp, Barr, Stevens, \& Cannatelli, 2010). Similarly, opportunities such as those offered to schools by the controversial Channel One have shown that schools are generally interested in partnering with for-profit businesses if it helps them provide greater services to their students at no cost (Blokhuis, 2008). Social enterprise offers struggling school administrators a hope for their stretched budgets.

Yet, this hope does not come without risk. Some studies have found that implementation of social enterprise based funding techniques can cause an organization to drift from its initial mission (Yunus, 2007; Page \& Katz, 2010; Hudson, 2009). Other organizations find that they are simply not ready to manage an organization that has all of the complexities of both the nonprofit and for-profit world (Moizer \& Tracey, 2010; Kirkman, 2012; Smith et al., 2012). Then there are the financial challenges. Many entrepreneurs get involved in social enterprise hoping it will solve their every financial challenge only to find that they still need at least some philanthropic support (Casselman, 2007). Added to this is the crowding effect, which means that for every dollar raised in social enterprise funds a portion of that dollar will generally be lost in crowded out 
philanthropic support (Smith et al., 2012). Social enterprise offers the promise of great financial reward, but it does not come without a potential price for the ill prepared leader.

While the promise of social enterprise as a source of funding for private education presents many uncertainties, one of the greatest is whether private school leadership is prepared to explore such options on any large scale level. Unlike public schools, private schools generally have a relatively small leadership team. This concentrated power means that the views of a few key individuals are likely to determine whether or not a school will even consider tapping into social enterprise revenue (Yaghi 2007; Yaghi 2008). As a result of this governing structure, an understanding of the views of these key individuals is essential to further study in this field.

\section{Definition of Terms}

Private School - Either religious or nonreligious schools operated by a private, nongovernmental organization (Sakellariou \& Patrinos, 2009).

Independent School - Also known as private independent schools, independent schools are a form of private school that operates independent of any outside governing organization (Jeynes, 2007; Davison \& Davison, 2009).

Voucher - A chunk of money that a parent or guardian can use to cover a portion of tuition expenses at a private or public school of their choice in lieu of enrolling in the public school system (Loeb, Valant, \& Kasman, 2011; Merrifield 2008).

Refundable Tuition Tax Credit - An amount of money taken directly off a family's tax bill which has the potential to result in a refund greater than the amount paid through payroll withholding or estimated tax payments throughout the course of the year (Merrifield, 2008). 
Nonrefundable Tuition Tax Credit - An amount of money taken directly off a family's tax bill that is limited by the amount of overall tax liability and thus cannot create a refund beyond that which has been paid in through the course of the year in payroll withholding and / or estimated tax payments (Merrifield, 2008).

Social Enterprise - An innovative organization led by a social entrepreneur that employs market practices to meet a social need in a sustainable manner (Trexler, 2008).

Achievement Gap - The gap between the educational achievement of students coming from more affluent backgrounds and those coming from backgrounds which provide them with fewer resources (Ladson-Billings, 2007).

Nonprofit Organization (NPO) - An organization that exists to provide services that are beneficial to society and do so based on their beliefs in the importance of meeting this need rather than for economic profit including the absence of any ownership interest that can be sold or transferred (Tolbert, Moore \& Wood, 2010).

Christian School - A school that focuses on the promotion or maintenance of Christianity while providing a complete academic education (Laats, 2010; Swezey, 2006; Zandstra, 2012).

Association of Christian Schools International (ACSI) - A member service organization consisting of over 5,000 Christian schools with a total enrollment of over 1,000,000 students (“ACSI Annual,” 2009) .

Socioeconomic status (SES) - An indicator of social class based on income, parent education level, parent occupation, and various other determining factors (“Definitions," 2007). 
No Child Left Behind Act - A law passed by the United States Congress in 2001 tying some federal funds provided to schools to their performance, redirecting money from under performing schools to provide supplemental services to their students (Umpstead, 2008).

National Association of Independent Schools (NAIS) - A national organization representing and providing services to independent schools (Davison \& Davison, 2009).

Independent School Management (ISM) - A national organization representing and providing managements services to independent schools (Jeynes, 2007).

Commercial Activity - Activity engaged in with the intent of generating a profit (Lunden, 2007; Browder, 2007).

\section{Statement of Issue}

As the cost of providing a private school education increases, many private schools are finding it increasingly hard to operate based on the income from tuition and philanthropic gifts alone (U.S. Department of Education, 2008). Unfortunately, new ideas on how to generate the additional revenue needed have been extremely limited, leaving a gaping hole in both the literature surrounding this issue and the budgets of individual schools. To this end, the field of social enterprise has great potential to address the problem of desperately needed additional funds. However, since little research has been done on the application of this approach to private education, there remains a great question as to whether administrators would be open to such a cutting edge approach. The answer to this question is important to policy makers both inside and outside of the 
school setting as it will inform how they approach a school with the idea of implementing a social enterprise based fund raising technique.

In relating to this broad need for additional research on the receptivity of private school administrators to social enterprise based fund raising techniques, I have chosen to focus this study on Christian schools. As a subset of the private school sector, Christian schools are often particularly hard hit by the growing difference between what many families can afford to pay in tuition and the real cost of educating their students. This can make managing Christian school finances a great challenge. If not handled well, this challenge of financing Christian education can become a source of tension within the school and can take away from the school's ability to achieve its mission (Hillen, 2008). Christian education is at a crossroads in many ways. At a national summit hosted by the University of Dayton, over 140 Christian educators convened to address issues facing Christian education. Of the categories they developed, two were related to finances ("The Dayton," 2009). The issue of financing Christian education is one that is on the mind of many educators. More information is needed to determine if administrators are open to social enterprise as a source of supplemental funds for their school.

Like public schools, Christian schools come in a diverse range of sizes, structures, and operational models. In an attempt to further narrow down this field, this study will focus specifically on administrators and board chairmen serving schools in the United States that are members of the Association of Christian Schools International and are located in their Mid-America region. The Association of Christian Schools International is a member service organization with over 3,000 member schools in the United States and 20,000 schools internationally serving over 5 million students (Association of 
Christian Schools International, n.d.). Its large size puts it in a position of prominence in Christian school circles. According to a recent survey, $71 \%$ of ACSI school administrators are concerned about tuition affordability (“ACSI Annual,” 2009). The size of this organization and the shared concern over tuition affordability on the part of its member schools make it a strategic sample with which to do this first study of the openness of Christian school administrators to the concept of social enterprise.

\section{Scope of the Study and Delimitations}

In this study I will seek to discover the degree to which ACSI Christian school administrators in the United States are open to the idea of implementing social enterprise based techniques into their overall fund raising efforts. In addition, I will seek to determine what specific social enterprise opportunities they would be open to. In understanding this it is important to understand the nature of the schools at which the leaders being surveyed serve. ACSI schools are Christian schools who utilize services provided by ACSI ranging from professional development to accreditation. As such they vary widely in size, socioeconomic makeup, curriculum, and many other areas. However, what binds them together is a commonly held core theology and philosophy. ACSI Christian schools are generally schools comprised of members of protestant Christian churches. They see God as the creator and redeemer of life. As a result, all of life then centers on bringing him glory. In the practical outworking of this belief, ACSI schools tend to put more emphasis on an individual responsibility to God rather than corporate. Philosophically they view parents as appointed by God to be the key caregivers for their children. The school is seen as an agent of the parents and the family rather than an agent 
of the state (Swezey, 2006). This common core philosophy and theology is the thread which binds ACSI schools together and forms the backdrop for this study.

This study focuses only on ACSI Christian school administrators in the MidAmerica region of the United States. While it can be reasonably hypothesized that these results would transfer to other ACSI Christian school administrators and board presidents and to some degree to Christian school administrators and board presidents at schools not affiliated with ACSI, further study will be necessary to establish this. It can also not be said for certain that these results would generalize to ACSI Christian schools in other countries. The cultural differences could bring about different views on social enterprise based fund raising techniques than those held by Christian school administrators in the United States. In addition, the results of this study also cannot be generalized to assistant administrators, parents, or any other decision making body within the school. Finally, this study focused on Christian schools with a student population of 300 or more. It cannot be assumed that the results of this study would transfer to smaller schools.

\section{Significance of the Study}

With the increased pressure on Christian schools to meet their financial obligations while keeping tuition affordable, many school administrators are scrambling for answers. Since little research has been done on applying new and innovative fundraising approaches to the Christian school context, Christian school administrators are left to pray and engage in what often amounts to sanctified guessing as to what is likely to work for their school. In addition, no research has been done on fundraising programs that effectively move beyond a dependence on altruistic donors. While research indicates that social enterprise is unlikely to solve all of a school's financial problems 
(Casselman, 2007; Smith et al., 2012), there is good reason to believe that if developed wisely over time it can be a benefit to the school's long term financial outlook.

While social enterprise has the potential to dynamically impact the financial future of Christian schools, no research has been done to indicate how receptive Christian school administrators and board presidents will be to this new approach. It is conceivable that these leaders may have concerns about the application of such new techniques. They may question how such an approach fits into a sound theological framework. They may also have many practical questions such as how such a program will impact the school's focus on its mission. While one can postulate what factors may be important to administrators, with no formal research having been done on this topic it is impossible to say with any confidence how Christian school administrators and board presidents feel about the application of social enterprise based fund raising to their school's repertoire of fund raising approaches.

This study is particularly strategic because of its innovative nature. The survey I will conduct will not answer all of the questions that must be answered regarding the potential application of social enterprise based fund raising to Christian schools. It will not delineate every objection that administrators may have. However, what it will do is generate discussion. It will for the first time raise this topic as a viable consideration for administrators and school boards. It will also show would be social entrepreneurs how ready Christian school administrators are for such innovation. This study is a foundational study which will hopefully pave the way for far more detailed research to come. 


\section{Methods}

Research Questions:

- Are ACSI Christian school administrators receptive to the use of social enterprise based fund raising techniques?

- Are there specific forms of social enterprise based fund raising techniques that ACSI Christian school administrators are more open to than others?

- Is there a statistically significant difference between the interest of lead school administrators and school board presidents in exploring social enterprise?

This non-experimental survey research focuses on the receptivity of ACSI Christian school administrators and board chairmen serving at Christian schools with an enrollment of 300 or more students in the Mid-America region to social enterprise based fund raising approaches. The survey asks Christian school lead administrators and board chairmen to rate the degree to which they are currently involved in a number of social enterprise related fund raising activities and then asks their degree of interest in exploring each concept along with the level of interest they expect their school board as a whole to have. Responses were given on an anchored Likert scale. Since the term social enterprise is not well known among Christian school administrators, survey items operationalize this concept by presenting administrators with specific scenarios which represent the use of different forms of social enterprise (Johnson \& Christensen, 2008). Data collected was quantitative in nature and was analyzed by calculating both the mean response and frequency distribution for the responses to each question. 
The sample consists of 104 Christian school administrators and board presidents from 52 ACSI Christian schools in the Mid-America region. The population includes all ACSI Christian schools in this region, avoiding much of the potential concern over sampling error. The population was limited to schools with an enrollment of 300 or more students to ensure that selected schools would have the resources needed to implement a social enterprise based approach to fundraising. The lead administrator and the board president / chairman were selected from each school as they are likely to be the most influential voices in deciding the direction of the school relative to these issues.

Initial surveys were mailed to administrators and board member in a standard legal sized white envelope. Surveys were hand addressed and contained a brief personalized cover letter along with the survey, a self addressed stamped envelope, and a hand written sticky note thanking participants for their time. Every effort was made to personalize this survey in a way that would bring about high response rates. Participants were given a deadline with sufficient time to complete the survey and return it but without stretching the time window out too much so that participants might tend to put off responding and forget about it. The list of recipients was later rechecked and any administrators or board members who should have been included in the population and had been missed in the first mailing were faxed copies of the survey with personalized cover sheets to keep the timing of their responses in general alignment with those surveys that had been mailed out.

Follow up surveys were sent by fax to all non-responders. Faxing the surveys gave an additional method for response and facilitated the return of a few additional surveys. To insure that waves one and two provided similar results, an analysis of 
variance (ANOVA) was done using the computerized statistical analysis program SPSS. ANOVA is a statistical analysis in which the variance within a subset of a larger group is compared with the variance between the subsets to determine if all subsets are likely to be a part of the same population or different populations (Johnson \& Christensen, 2008). In the case of this survey, ANOVA will be used to insure that the results for both waves of the survey are similar in their findings and that there have not been any confounding variables introduced such as a history effect that could have caused a change in the results between the waves.

The primary potential threat to external validity in survey research is that the sample provided by those who respond to the survey will not be representative of the population the results are to be generalized to. One element of this is the threat that an inadequate response rate will result in those who return the survey being an unrepresentative sample when compared with the population to which the results are to be generalized. This was accounted for by following up with administrators to achieve a response rate in excess of 55\%. With all members of the population being sent surveys and a response rate over $50 \%$ I can be reasonably confident that the sample data set is representative of the population (Nulty 2008; Vogt, Gardner \& Haeffele, 2012). There are no other known threats to internal or external validity. 


\section{Chapter Two: Plenary Review of the Literature}

\section{Historical Background}

From the earliest days of the United States, education has been seen as a topic of great importance to the common good. Starting in 1642 in what was then the colony of Massachusetts, legislation was enacted to insure that public schools were funded and available to provide education for young people (Verstegen, 2011). Funding for these early American schools took on a variety of forms. In most cases this involved some combination of state funding, local funding, and tuition which was often referred to as a rate bill (Beadie, 2008; Verstegen, 2011). The distribution of these funds differed by location and by school type (Beadie, 2008; Go \& Lindert, 2010). In many locations capital for the construction of school buildings came primarily or even entirely from private sources with public money being used only to cover the cost of operating the school (Beadie, 2008).

The financing of these early schools was an ongoing source of debate. Founding fathers such as Thomas Jefferson proposed that education be free to all and yet prior to the civil war this was generally more of a theory for the scholars than a practical reality (Beadie, 2008; Verstegen, 2011; Salmon, 2010). In fact, trends in enrollment in the northern part of the United States showed a higher level of school participation arguably caused in part by the lower cost of offering mass education in that setting (Go \& Lindert, 2010). While the widespread availability of education in the United States has had a 
profound impact on its history, the issue of how to best finance this education has never been far from the surface.

After the civil war free public schools became increasingly common (Beadie, 2008), yet education was still far from equal. It would take a century and a half of court battles to bring the United States to where it is today. Most of these early battles centered on the idea of equality. Men such as Ellwood Cubberly argued persuasively for less local funding of schools to create a greater level of equality (Verstegen, 2008). By the 1850s Americans were spending a greater portion of GDP on education than any other country in the world except for Prussia. While this figure is remarkable, the percentage of that figure coming from tax dollars was far less impressive. (Go \& Lindert, 2010). Thus, in spite of the work of very dedicated men, American schooling remains a system of profound inequality driven in part by inequality in funding with some families simply being priced out of a quality education.

\section{Modern Struggles in School Finance}

This challenge in financing schools is not limited to a time period in the past that can be dismissed nostalgically as one of the rites of passage of a developing nation. Almost 350 years after the first formal education systems were setup in the state of Massachusetts (Verstegen, 2011), American schools are still fraught with financial challenges. These challenges are nearly universal, spanning districts coast to coast (Donlevy, 2010; McKinley \& Phillis, 2008; Salmon, 2010) from rural (Williams \& Nierengarten, 2011) to urban (Crampton, 2010; Ladson-Billings, 2007). In Virginia, one of America's oldest states and a state full of national history, the voting public was slow to accept taxation for the purpose of offering public education that would be completely 
provided at taxpayer expense (Salmon, 2010). Today Virginia is rated as having one of the least funded education systems in the country when looking at funding for education as a percentage of overall personal wealth putting the provision of even a basic level of education at the mercy of federal stimulus funds (Salmon, 2010).

An examination of the school system in the heartland state of Ohio shows similar challenges. Five major rounds of litigation in the state's highest court system have resulted in an overall ruling that the state's model for funding schools is unconstitutional. While the courts have put the responsibility for solving this problem back on the state's legislature, over a decade of attempts by the legislature have left the state's school system still falling short of the constitutional standard. In the DeRolph II court ruling Judge Resnick gave the following guidelines for what a constitutionally appropriate state public education system would look like. She noted that such a system would be adequate in four areas: teachers and support personnel, buildings, textbooks \& materials, and technology. As fundamental as each of these areas seem, the state's general assembly is still attempting to find a way to finance an education which provides adequate and equitable quality in each of these areas (McKinley \& Phillis, 2008).

Moving to the west coast, the state of California has not fared much better. Its schools fail to distribute funding evenly with the most disadvantaged students seeing the least resources (Socias, Chambers, Esra, \& Shambaugh, 2007). Limited funds and growing challenges have left California with some of the lowest performing pupils in the country (Tang, 2011). In this atmosphere a new wave of legal challenges to educational funding is being fostered, a challenge to adequacy and equality that is based on the alignment of the state's schools to the state's educational standards (Tang, 2011; Slater 
2011). This, combined with educational spending that is capped by law (Tang, 2011), makes the future of education in the state of California into a bit of a roller coaster ride as the rest of the nation watches.

These challenges to the way in which finances are handled in state public school systems are not limited to these three example states. Similar litigation has taken place in 44 of the 50 states (Tang, 2011) and it is now hard to imagine a state in the union in which school finance is not a challenge. Not only do these challenges span from coast to coast, they affect communities of all sizes. In a recent study of school administrators in rural Minnesota, two basic categories were identified as the primary areas of challenge. One of the two was finances. Within this category the two primary concerns were balancing the budget and managing transportation. Rural schools face special challenges. They service students more geographically spread out than students in other areas, and they face complex taxation structures with more of the land being undeveloped and used for agriculture. In light of this, rural areas struggle to provide a quality education to their students in part due to the challenge of financing this education (Williams \& Nierengarten, 2011).

Urban areas are also affected by significant challenges in providing a quality education to their students. Generations of providing urban students with inadequate resources have left society with a system that produces students coming from its urban school district with an inferior education and performance that is so uncompetitive that it has been coined in the literature as the "achievement gap" (Ladson-Billings, 2007, p. 1). As one scholar notes, society owes a mountain of debt to these students who have been so neglected for generations (Ladson-Billings, 2007). While the challenges faced by urban 
districts are not strictly financial, the lack of resources does contribute to the challenge (Crampton, 2010). Research suggests a connection between resources and academic achievement (Jimenez-Castellanos, 2010). In light of this it should not be surprising that the nation's urban districts are some of the most affected by the challenges of funding education in the 21 st century.

These challenges in funding education, which affect a growing number of districts throughout the country (Donlevy, 2010), stand in the way of their ability to perform up to their potential. These challenges can be seen in areas such as adoption of technology where some schools struggle to keep enough modern technology available to their students to prepare them to perform in a technologically advanced work environment (Metz, 2010). In addition, funding makes it challenging for schools to provide the resources to underperforming students that would allow them to be successful. This is evidenced in the rhetoric of the debate surrounding the No Child Left Behind Act, a law introduced to raise the standards of America's public schools, but criticized as "an unfunded mandate" (Umpstead, 2008, p. 194; Duncombe, Lukemeyer, \& Yinger, 2008). Added to this current challenge is the rate at which educational costs continue to rise. A 2011 report from the National Center for Education Statistics shows an increase in per pupil expenditures in U.S. public schools of 39\% from the 1989-1990 school year to the 2007-2008 school year in constant inflation adjusted dollars (Aud, Hussar, \& Keena, 2011). This means that school districts that were already hard pressed to finance a quality education are now having to come up with even more dollars. The literature on America's public schools is replete with examples of school funding challenges, 
challenges which make it more challenging for teachers to prepare a world class citizenry for the next generation.

America's public schools are not the only schools facing financial pressure. Private schools that once offered parents an alternative to the public school system are increasingly struggling to survive (Cortina \& Frey, 2009; O'Keefe \& Scheopner, 2009; Looney, 2009; Mitchell, 2009). While the per student expenditures at America's public schools increased by $39 \%$ in the time period from the 1989-1990 school year to the 20072008 school year in constant inflation adjusted dollars, the cost of education at a noncatholic religious school went up 64\% (Snyder \& Dillow, 2011; Snyder, 1993) and the cost of a catholic school education went up $229 \%$ all in approximately that same time period and all in inflation adjusted dollars. While remarkably little has been written about the cause of this increase in the cost of private school education, statistics seem to reveal two primary causes for non-catholic private schools. The first is a decrease in studentteacher ratio of almost 30\% for these schools during this time period. The second is increased compensation for private school teachers amounting to a rise of almost $20 \%$ beyond inflation for the average teacher. For Catholic schools a third and perhaps more important causes is added: the declining number of nuns resulting in less of what was once a very low cost teaching force (Meyer, 2007; Kruska, 2008). This rapid increase in cost for a private school education leaves private schools in a challenging position.

This challenge is best represented in the literature as it relates to Catholic schools. Catholic schools are the largest private school system in the United States ("Making God Known," 2008; Meyer, 2007). At their peak they educated 1 in 8 American school children. Yet, today Catholic schools are in decline. The average enrollment today is half 
of what it was at the peak of the Catholic school movement (Meyer, 2007). While several reasons have been given for the decline of catholic schools (James, 2007), one of the key challenges faced by catholic schools is the rising cost of providing a catholic school education and the decreasing number of families who are able or willing to pay it. In a recent survey of families whose kids were enrolled in catholic elementary schools but were not planning to enroll their child in a catholic high school, economics was given as the top reason for not continuing in a Catholic school (Huber, 2007). Families are being faced with the tough choice of pulling their child out of catholic schools in order to meet the other budgetary needs of their family (Kruska, 2008) while the population of catholic schools becomes increasingly upper class (Huber, 2007).

In the face of these challenges Catholic school leaders have scrambled to restructure their schools to meet the demands (James, 2007). In 2005 the Catholic bishops issued a report titled "Renewing our Commitment to Catholic Elementary and Secondary Schools in the Third Millenium" (Kruska, 2008). It called for a revitalization of catholic schools in areas relating to both quality and affordability. To address this many catholic schools have reexamined their management and fiscal structures. In addressing these concerns five basic models have been used (Kruska, 2008). The first is the "cost-based" model (Kruska, 2008, p. 26; James, 2007, p. 293). In this model tuition is raised to the actual cost of providing the education. Subsidies are then focused on the students with the greatest financial need. The goal is to maximize access to Catholic schools. A second model is the "negotiated tuition" model (Kruska, 2008, p. 26; James, 2007, p. 294). In this model families negotiate their tuition with the school leadership on a yearly basis. A third approach to managing tuition is the "stewardship model" (Kruska, 2008, p. 28; 
James, 2007, p. 295). In this model families are simply asked to exercise significant stewardship of their resources in giving regularly to the church in accordance with their income. The church then agrees to cover all of the student's education cost so that there is not a true tuition assessed and donations to the church are tax deductible. The final truly tuition based model is the "hybrid model" (James, 2007, p. 296). In this model tuition is set at the actual cost of providing the education just as in the "cost-based" model. Families who cannot afford full tuition can apply for financial aid and are guaranteed that the total of tuition and charitable giving will never have to exceed $8 \%$ of their income. The fifth model which will be addressed in more detail later on is the "business based model" (Kruska, 2008, p. 28). While this model takes different forms, it relies in a large part on fiscal contributions from businesses to defray the cost of tuition. Yet even with these changes, the challenge of keeping catholic schools open is still very real ("Making God Known,” 2008; James, 2007; Kruska, 2008; Meyer, 2007).

In addition to the Catholic schools, independent schools of all types are facing financial challenges. While not as well represented in the literature, these schools struggle to keep themselves within reach of their target market. Of the organizations writing on the topic of independent school affordability, the most prolific have been the National Association of Independent Schools (NAIS) and Independent School Management (ISM). In their 2009 book titled Affordability and Demand, a total of 14 authors representing NAIS schools across the country wrote on the topic of school affordability. In this book the authors give an overview of the current state of private school affordability. As one of the contributors, Looney (2009) points out that while a 2006 public opinion poll noted $55 \%$ of respondents viewing independent schools as providing a superior education to 
public schools, only about $10 \%$ of American school age children attend some form of private school. He argues that the reason for the discrepancy is based on where schools fall in the perceived value / perceived cost continuum. In order to create high demand Looney argues that the perceived value of a school must far outweigh its perceived cost. To the degree they fail to do this, schools miss out on potential students.

Similarly, NAIS president Patrick Bassett (2010) tells a humorous story of a school administrative team meeting in which the pressure of dealing with keeping schools affordable in the current economy makes the school's headmaster consider a change of careers. While Mr. Bassett seeks to keep a light hearted tone and shares encouragement in the area of philanthropic giving, he further reinforces the need to keep schools affordable. This focus on affordability is a key tenet of the NAIS position on school finance and one which seems incredibly relevant in light of the current financial challenges faced by private schools of all types.

Independent School Management (ISM) takes a different but complementary approach. While they disagree with NAIS that making independent schools affordable to the middle class should be a high priority, the argument they do make leads to the same ultimate conclusion for many independent schools, particularly those with a religious emphasis. ISM points out that "a school's general commitment should be to attract and retain the mix of students implied by its mission" (Jeynes, 2007, p. 38). In their literature ISM consistently encourages independent schools to look at their mission when determining pricing whereas NAIS is a consistent advocate for diversity in all private schools and keeping all independent schools as affordable as possible (Jeynes, 2007; Davison \& Davison, 2009). While this causes frequent banter between the two 
organizations the end result is the same for many schools, particularly Christian schools who see a Christian education as a beneficial part of the discipleship process for Christian young people and desire to make a Christian education affordable to all families who desire it (Laats, 2010; Swezey, 2006).

The point that the price of private schools in general often keeps middle class families from attending these institutions can be found dotted throughout the literature. In their description of U.S. schooling German authors Kai Cortina and Kristina Frey note that paying for a private education in the United States can often be a burden for some families (Cortina \& Frey, 2009). Similarly, Garnett (2010) makes an argument for the use of tax incentives to keep what she argues is a valuable resource within reach of middle class families. Adding to the point, the National Center for Educational Statistics, in their publication "The Condition of Education 2011," notes a decline in enrollment in catholic schools and other Christian schools (Aud et al., 2011). This decline in enrollment as parents are facing an ever increasing challenge of paying for a private school education leads to a challenge for private schools, particularly those of a religious nature.

Answering this challenge will be the focus of this study.

\section{Facing the Challenge of Financing Private Schools}

In addressing the challenge of keeping a private school education accessible to the middle class, private schools have employed a wide variety of strategies. The first and most common is appealing to philanthropic support either for the purpose of keeping overall tuition low or to cover the cost of financial aid. Colson (2009) writes that "During the 21 st century, all independent schools will be more reliant on annual, capital, and planned giving revenues and on endowment income to ensure their financial 
sustainability" (p. 4). Yet this does not seem to concern her as she paints a bright future for philanthropy at independent schools, noting that total philanthropic giving to nonprofits has climbed in real dollars since 1955 with the exception of only one year that can be explained by a change in tax law the year before. NAIS president Phil Bassett (2010) notes a similar trend. Adding to the point, Strickland (2009) points out the increasing role of philanthropy in the American economy as a whole.

Historically, one of the key sources of philanthropic support for private schools has been giving to local churches who in turn funnel a portion of this money to the church school. The best represented example of this in the literature again comes from the Catholic school movement. As recently as 1969 church support amounted to $63 \%$ of income for Catholic schools, although it is worth noting that this has now fallen to closer to $25 \%$ (James, 2007; Kruska, 2008). Within the catholic community, a variety of revised funding approaches have been devised to address the problems of affordability and access. In each case they involve some form of church support (Kruska, 2008). While the future seems bright for philanthropic support to private schools it does not seem to be enough in itself when parents are still citing finances as the number one reason for not continuing at a private school (Huber, 2007) and private school enrollment is still falling (Aud et al., 2011). Thus, private schools have looked to other funding sources to augment what they are able to bring in through philanthropic support.

One of the other sources of funds that some private schools have turned to is government vouchers (Loeb, Valant, \& Kasman, 2011; Sutton \& King, 2011). Vouchers have been a source of a great deal of controversy in recent years. Some states have found ways to completely ban them (Sutton \& King, 2011) while others have embraced them 
(Loeb et al., 2011). Where they are embraced by law, some private schools are more open to them than others as a way to meet the needs of students who could not otherwise afford to attend their schools. The protestant Christian school group, the Association of Christian Schools International (ACSI), offers a great example of this debate. Within this group big names such as Dr. Paul Kienel have come out strongly against vouchers, referring to their acceptance by Christian schools as "the beginning of the end," (Swezey, 2006, p. 263) while former ACSI president Ken Smitherman and the ACSI leadership as a whole favor the acceptance of vouchers (Swezey, 2006). Overall public opinion seems to be swinging in favor of vouchers. A 2011 public opinion survey conducted by Education Next showed an 8 percentage point increase in support for school vouchers between 2010 and 2011 (Howell, West, \& Peterson, 2011). Some private schools are finding this public support for vouchers to be a stabilizing force in a time of otherwise falling enrollment (Meyer, 2007). While vouchers have gained acceptance in some communities, they are still far from widespread (Wolf, 2009). Some states have successfully argued that amendments to their state constitutions commonly known as Blaine Amendments prevent vouchers from being used at schools with any form of religious affiliation. Where vouchers are permitted, they are often only open to students in a select group, which may include low income students, students assigned to failing schools, or students within a limited geographic zone (Merrifield, 2008). Whether or not a school chooses to take advantage of vouchers where they are available may depend on the philosophy of the school leadership. At the same time, given their controversial nature and limited scope, it seems unlikely that vouchers will solve all that ails private school funding any time in the near future. 
An alternative to direct vouchers that has received greater acceptance among some groups is tax credits as a means for helping families pay for a private school education. While vouchers may receive more public attention, tax credits pay for more students to attend private schools than do vouchers, and support is growing (Figlio, 2011). Tax credits have the benefit of reallocating money that has not yet become a government asset. As a result, it is not subject to the same regulations that vouchers may face (Trebbe, 2009). Advocates of free market reforms to education trumpet tax credit as a less regulated form of promoting school choice (Coulson, 2009; Coulson, 2011; Huerta \& d'Entremont, 2007). Tax credits may be either refundable or nonrefundable and may be available only to the family of eligible students or to individuals and companies who contribute to scholarship funds. Each approach has its advantages and disadvantages. A refundable voucher encourages families with low tax liability to participate in a greater way in private education. At the same time, it allows for some of the same limitations faced by vouchers because the government, in at least some cases, is writing a check. Nonrefundable vouchers are seen by some as less likely to attract government limitations, but at the same time fail to offer a significant incentive for lower income students to participate in private education. Tax credits for contributing to scholarship programs offer a greater benefit to low income families, but limits impact to lower income students (Merrifield, 2008). While tax credits as a tool for opening the doors of the private school to a wider audience has gained popularity, it still has plenty of opposition. Legislators have found that teachers unions and other long standing defenders of traditional public education will vehemently oppose this type of free market reform (Loeb et al., 2011; 
Wilbur, 2008). While tax credits are a growing trend, like vouchers, their scope is still far too limited to make a private education an option for the majority of American children.

One final method of addressing the financial challenges faced by schools dates back to the late 1800 's, but has seen an explosion in popularity since the early 1990's. Although not entirely new, the idea of commercial activity in schools seems to be growing. Arizona State University's Commercialism in Education Research Unit divides commercial activity in schools into eight categories which have helped to create a framework for other research studies: sponsorships, exclusive agreements, sponsored educational materials, electronic marketing, fund raising, incentive programs, appropriation of space, and privatization (Lunden, 2007; Browder, 2007). Betty Culbertson, in her 2009 dissertation, notes that most administrators she surveyed found fund raising to be worth the time they invested in it. The literature is clear that commercialism has entered into the world of education in a significant way ranging from the controversial Channel One (Blokhuis, 2008) to the sale of candy to fund class field trips.

Commercial activity in U.S. schools has been met with mixed reviews. Some activities have been determined to be acceptable, primarily those not directly impacting the classroom, with others being seen as inappropriate ways to generate extra funding (Browder, 2007). Some naysayers suggest that the percentage of the budget brought in through commercial activity in schools does not justify the attention that has been given to it (Brent \& Lunden, 2009). Others are concerned about specific issues within commercial activities in schools such as the health impact of food sold as a part of fundraisers (Kubik, Lytle, Farbakhsh, Moe, \& Samuelson, 2009). The overall consensus 
among school administrators in the public school setting seems to be one of attempted moderation in which companies are allowed limited promotional rights in exchange for providing goods and services that will benefit the school and its students while rejecting anything that more closely resembles the direct promotion of a product by the school (Lunden, 2007; Browder, 2007). In spite of the recognized need for caution, over $50 \%$ of public schools in New York state participate in commercial fund raisers while over 50\% also participate in commercial incentive programs such as the Book It program offered by Pizza Hut. A large number of public school administrators simply find commercial activity to be a necessary part of funding the standard of education they wish to offer to their students (Lunden, 2007). Yet, while commercial activity is also applied on some level in private schools, no formal studies have yet been done to measure the degree to which commercial activity takes place in private schools or the openness of school administrators to this type of activity. This is one of the gaps in the literature that this study will address.

\section{Social Enterprise}

Schools are not the only organizations choosing to participate in the commercial world in order to fund their operations. In recent years the term "social enterprise" has been added to the lexicon of many not for profit organizations. Jeff Trexler refers to social enterprise as "charity's web 2.0" (Trexler, 2008, p. 67). Its popularity as a topic for discussion in the literature has exploded in recent years. The next section of this literature review will examine the topic of social enterprise for the purpose of ultimately applying scholarship from the broader nonprofit field to the topic of school funding. 
One of the greatest challenges in studying the field of social enterprise is arriving at a clear definition of the term. As a relatively new field, the nomenclature of social enterprise is still being refined (Bielefield, 2009; Teasdale, 2012; Trexler, 2008; Trivedi, 2011). Widespread disagreements exist in spite of the fact that numerous paradigms have been suggested for attempting to define what social enterprise is (Trexler, 2008). Adding to the complication of this issue is the fact that definitions tend to differ by geography, most notably between the United States and Europe (Kerlin, 2010; Trivedi \& Stokols, 2011). For example, in the United States, social enterprise is seen primarily as a way to build an element of sustainability into nonprofit organizations, whereas in Europe the focus is more one of creating additional social value (Kerlin, 2010).

In spite of this widespread disagreement, there are certain characteristics that seem to be held in common among the scholars writing on this topic. These commonalities have led Chitvan Trivedi and Daniel Stokols to come to a four part definition of a social enterprise that will serve as a working definition for the sake of this study. First, social enterprise has a social purpose (Teasdale, 2012; Trivedi \& Stokols, 2011; Trexler, 2008). While widespread disagreement exists as to what even qualifies as a social purpose (Trexler, 2008), this issue is a little clearer in relation to schools. Most scholars would agree that benefiting the education of children is a social purpose.

A second element of the definition of a social enterprise is that its social purpose is in some part supported by earned revenue (Kerlin, 2010; Massetti, 2008; Katz \& Page, 2010; Popierlarski \& Cotugna, 2010). This serves as a key distinguishing element of social enterprise. By legal classification a social enterprise can be a for profit corporation or not for profit (Katz \& Page, 2010); however, at least a portion of the profits earned 
must be directed to a social purpose. This still does not give a clear definition as it does leave the question open as to whether a store that donates $5 \%$ of its profit to a philanthropic cause can truly be considered a social enterprise. However, it does at least provide some focus. Furthermore, this element distinguishes social enterprise from the broader term social entrepreneur. A social enterprise will always involve earned income that helps to support a social cause, the work of the social entrepreneur may or may not (Popierlarski \& Kotugna, 2010).

The third and fourth elements of a working definition for social enterprise are that a social enterprise is, by definition, innovative and the work of an advocate for a social cause (Kirkman, 2012; Trivedi \& Stokols, 2011). This concept of innovation is present in at least most cases and fits with the fact that social enterprises are organizations that look for new solutions to age old problem. They seek to pair an innovative structure with a problem that requires an innovative solution such as the funding of schools. As such, social enterprise is inextricably connected to the work of the social entrepreneur; an individual who trumpets and champions social change (Trivedi \& Stokols, 2011). Creating innovative solutions to social problems requires an innovative thinker who is passionate about the cause.

Based on this work, the Social Enterprise Institute has divided social enterprises into three categories: employment, fee for service, and entrepreneurial support. The first category includes common social enterprises such as Goodwill Industries and Industries for the Blind. These organizations exist for the purpose of helping individuals access gainful employment that they might not otherwise be able to access. The second category is one that includes most private schools in their existing form and nearly all universities 
whether public or private. In its first form it involves the offering of a service for which clients pay a fee that covers part of, but not all of, the cost of providing the service. This is the mode in which most private schools operate. In its second form a fee for service model involves the sale of goods or services unrelated to the mission of the organization for the purpose of producing funds. Most standard school fund raisers would fall into this category, but it could be extended more broadly to include organizations such as thrift stores that fund scholarships for local Christian schools. The majority of schools only operate in this mode on occasion and it is in this area that schools have an opportunity to more fully implement scholarship from the field of social enterprise. The final category is the one that has received the least attention in the literature. It involves making connections between people and goods or services in a way that either increases the access of the seller to a purchasing market or increases the access of the buyer to goods that are more affordable or of a higher quality (Popielarski \& Cotugna, 2010).

In spite of the challenge of properly defining and categorizing these unique, hybrid entities, organizations choose to participate in social enterprise because it brings in money, a commodity that many advocates for social causes find themselves in desperate need of. This, at least in theory, allows organizations to diversify their funding pool and become less reliant on philanthropic contributions (Smith et al., 2012). Jason Blokhuis illustrates this in his writing about the controversial "Channel One" news programming that is broadcast into many classrooms around the nation every school morning. He notes the ethical concerns with this type of a partnership and yet notes its pervasiveness as schools see the benefit of the technology this company supplies to partner schools (2008). A more positive example can be found in the girl scouts. Every year the girl scouts sell 
their famously tasty, yet famously expensive, cookies. These sales net a total of over $\$ 400$ million dollars a year for the organization (Smith, Knapp, Barr, Stevens, \& Cannatelli, 2010). It is no surprise that they keep selling cookies. Similarly, schools engage in commercial activity to help support their mission of providing a quality education to every student in their building (Lunden, 2007). While debate still exists about whether the benefits of social enterprise outweigh the potential ills, the fact is that social enterprise, when done well, brings in money that enables organizations to fund their mission.

Even with its significant financial promise, social enterprise does come with a series of potential pitfalls which should not be ignored. The first is that social enterprise is an ill-defined field. This lack of a clear definition moving forward has the potential to turn the field into a passing fad (Trexler, 2008). This is further complicated when the organization itself faces the challenge of living between two worlds: maximization of profits and maximization of social benefit. This creates a challenge which in many cases results in the organization drifting to a profit maximization mode (Yunus, 2007; Page \& Katz, 2010; Hudson 2009). This issue should not be underestimated and must be handled with care. However, it can be overcome with effective leadership (Smith et al., 2010). In addition to the challenge of identity drift, social enterprises must face the challenge of dealing with the complexity of running a double bottom line operation (Moizer \& Tracey, 2010; Kirkman, 2012; Smith et al. 2012). For many organizational leaders accustomed to the not-for-profit world, dealing with the realities of a for-profit business can pose a challenge (Kirkman 2012; Smith et al., 2012). As one article notes, "Many NPO executives became so enthralled with the profit-generating potential of SEs 
that they ignored the complexity of implementing the innovation and their organization's capability to manage it" (Kirkman, 2012, p. 143). Alternately, leaders more accustomed to the ease of business metrics to measure the outcomes of their efforts may find measuring the social return on investment to be an equally daunting task (Meadows \& Pike 2010; Ryan 2008). Social enterprise is a complex field requiring the expertise of a skilled leader well versed in both the philanthropic world of dealing with foundations and promoting social outcomes while also possessing the business savvy necessary to manage the for profit element of the organization (Kirkman, 2012; Smith et al., 2010; Smith et al., 2012).

Perhaps the most delicate challenge of managing the complexity of a double bottom line organization is in dealing with the fact that it is rarely possible for an organization with a social purpose to be completely financially self-sustaining (Casselman, 2007), and thus the development of for-profit opportunities must be balanced with the concerns and desires of donors. One of these concerns is mission consistency. In other words, the literature suggests that the fit of the social enterprise to the social mission of the organization is critical. In addition, the overall attitude of donors towards the social enterprise, and the perceived entrepreneurial competence of the organization shown through the management of the social enterprise, impact overall intent of donors to continue to provide philanthropic donations. Even when all of these areas are handled well, the literature finds an overall "crowding-out effect" in which the introduction of an additional revenue source has an inherent negative effect on existing funding sources (Smith et al., 2012). Involvement in social enterprise is not a risk free venture. If it goes well, it could mean increased income, but if it goes poorly it can lead to 
less income than was available before the social enterprise option was explored due to decreased donor support.

In addition to the practical and missional challenges of living in two worlds, organizations can face legal challenges when trying to operate a social enterprise in a legal climate which is primarily centered on the two pure models of for profit and not for profit corporations. The not-for-profit legal entity is well suited to an organization existing largely for a social purpose. However, its prohibition against distribution of any of the money that comes in makes it a difficult model for organizations needing extensive capital for startup or expansion (Reiser, 2010; Kelley, 2009). Likewise, the traditional for profit model does not fit well for an organization whose goals are other than just profit maximization as the organization may run the risk of funds and assets designed for social purposes being used by future owners for profit making purposes (Page \& Katz, 2010; Reiser, 2010; Kelley, 2009). In addition, the organization exposes itself to legal liability as shareholders or partners may be able to sue as a result of decisions made to promote the organization's social mission at the expense of profit maximization (Reiser, 2010; Kelley, 2009).

While the legal challenges noted above are real and may pose significant barriers to social enterprise, they can be overcome. Thomas Kelley notes that enterprising organizations have taken two basic approaches to handling the legal challenges posed by the dual mission of the social enterprise. The first has been to find ways to work within the existing laws which has taken on several forms. Some organizations simply choose to organize as either a for-profit or a not-for-profit corporation. Those that organize as forprofit corporations count their charitable work as business losses which counteract at 
least the majority of the tax liability they would have otherwise faced based on their earned income. Other organizations have chosen to work between two organizations which are separate for legal purposes but work together toward a common goal. One branch of the organization is organized as a for-profit company to carry out the commercial goals of the organization while the other branch is organized as a not-forprofit corporation to carry out the social goals. Finally, some choose to employ the flexibility of the LLC organizational structure to design LLCs in which those controlling the decisions of the organization and those receiving the greatest financial payout may not be the same (Kelley, 2009).

As a way to expand on this last concept, a number of states have formed a new type of LLC known as a Low Profit Limited Liability Company (L3C). These organizations build on the flexibility of the LLC structure for social enterprises by creating a separate legal entity catered to the needs of these double bottom line organizations (Lang \& Carrot Minnigh, 2010; Schmidt, 2010; Kelley, 2009). The L3C, at least in theory, allows for investments from private foundations under IRS law and creates a brandable entity for social enterprises that allows them to attract both private foundation investments and corporate sponsorships (Kelley, 2009).

In weighing out the potential benefits of social enterprise with the challenges, the literature provides a relatively mixed review of this approach to funding social causes including schools. The early writings on social enterprise were overwhelmingly positive with early authors portraying social enterprise as the solution to all that ails the nonprofit world (Kirkman, 2012; Trexler, 2008). Yet as ideas were tried the tone of the research became more cautious (Kirkman, 2012). As noted, current research on the viability of 
social enterprise tends to be more mixed with some in favor while others come out strongly against it (Trexler, 2008). Others take a more moderate view, arguing that social enterprise should be seen for what it is, a relatively new and unproven concept that should be engaged in slowly and cautiously (Raymond 2010).

This caution seems well advised and yet does not seem to be the sounding of the death knoll for social enterprise as a tool to be used in funding education. It is true that schools must approach social enterprise in ways that are consistent with their mission (smith et al., 2012) and appreciate the complexity of this endeavor (Moizer \& Tracey 2010; Kirkman 2012; Smith et al., 2012). Yet as they do so, the literature contains plenty of examples of the successful application of social enterprise in ways that either directly connect with schools or suggest the potential success of this strategy when used by schools. A prime example can be found in two community colleges that, out of a need for greater cash flow, turned to a more entrepreneurial approach. When Springfield Technical Community College found themselves in need of cash, they turned vacant space into a technology park that they lease out. The school is also renovating other buildings not currently being used for classroom space to create earned income to supplement the school's budget. Central Piedmont Community College in Charlotte, North Carolina took this a step further, founding Central Piedmont Community College Service Corp. This organization is designed to use the school's resources to provide fee based services that generate revenue for the school. This includes using the existing faculty to create textbooks that are published and sold, DVD resources, etc. These organizations and others have encountered a great deal of success applying a social enterprise approach to community college funding (Violino, 2007). 
At the secondary level, there is the well publicized Cristo Rey network. These schools grew out of a desire on the part of a number of Jesuit priests to provide a quality private education to students in a poor Chicago neighborhood. These religious men saw the needs of the people of this community and knew the future the children of this neighborhood were condemned to if left without better educational options. Yet, the cost of a private school education was simply out of reach for these families many of whom would have had to give up $25 \%$ of their annual income just to pay tuition for one of their children. Not willing to give up this cause, these bold leaders proposed a partnership with local businesses in which entry level clerical positions would be split among a group of high school students. Each student would work one 8 hour shift per week with all payment for the work going to the school to finance their tuition. With an extended school day students would receive a college preparatory education in the remaining four days of the school week. This bold idea turned first into the Cristo Rey school and then into the Cristo Rey network as the idea took off. Today $90 \%$ of Cristo Rey's graduates go on to participate in higher education and hundreds of students are being shown a way out of poverty through hard work (Couture, 2007; Kearney, 2008).

In light of the promise of social enterprise for enhancing a school's income stream, NAIS author Robert Sedivy (2009) sets aside several pages of his chapter on cost containment and revenue growth strategies in the NAIS book Affordability and Demand to promote entrepreneurial activity. Although he does not use the term social enterprise, Sedivy ties together many of the lessons learned within the field of social enterprise. He starts by cautioning school leaders of the importance of only engaging in revenue generating opportunities that are in line with the school's mission. He also notes the 
complexity of financing startup entrepreneurial projects. Yet the tone in all of this is remarkably positive as he encourages school leaders to explore ways in which they can use their existing facilities and faculty to generate new streams of revenue through entrepreneurial activity that the nonprofit world would categorize as social enterprise.

Considering the mixed reviews that social enterprise has received in the academic literature and yet the overwhelming need for additional solutions to school funding challenges and the potential promise of social enterprise to aid in this area, a question still remains as to how school leaders will receive this type of innovation. School and social enterprise leaders considering such concepts are at a significant disadvantage in that most of the research up to this point on the topic of social enterprise has been theoretical and / or case study based with very little quantitative research taking place (Douglas, 2008). In examining the attitudes of school leaders toward commercial activity in public schools, the literature is a little more helpful. Two doctoral dissertations both completed in 2007 have examined this subject. Bobby Browder of Virginia Polytechnic and State University studied the perceptions of superintendents toward corporate advertising in Virginia public schools. Similarly Stephen Lunden of the University of Rochester studied what schools in the state of New York are actually doing within several categories of business related activity. While each of these studies moves the scholarship forward, they fall short of assessing attitudes towards a true social enterprise based approach to raising additional funds for schools. In addition, each of these studies takes place within the public school environment. Yet, in today's economic world, one of the most challenged school systems is the nation's private evangelical Christian schools. This study will add to the existing literature on school funding and social enterprise by determining the attitudes of Christian 
school leaders in school belonging to the nation's largest association of evangelical Christian schools (The Association of Christian Schools International) toward social enterprise based funding techniques.

\section{Summary}

In reviewing the current literature on the topic of school funding as it relates to social enterprise, the existing literature creates a picture of great need. The United States has a history of financial struggles in financing its schools. This struggle has continued into modern times. The funding struggle is magnified in the nation's private schools, which lacking the broad financial base of the public school system, often struggle to keep a private education affordable to a broad spectrum of American families. In addressing this struggle private schools have often looked to philanthropic giving as a key source of support. In addition, private schools have looked to government support in multiple ways. Finally, some enterprising schools have turned to commercial activity as a source of needed revenue. The limited research on commercial activity in schools has shown public school administrators open to it on a limited basis while seeking to separate it from the classroom itself.

In specifically addressing the commercial activity approach to revenue generation, a survey of the literature on the field of social enterprise was reviewed. This started with an understanding of social enterprise as an organization that has a social purpose, is supported by earned revenue, is innovative, and is the work of an advocate for a social cause. Based on this, social enterprises were found to be divided into three basic categories: employment, fee for service, and entrepreneurial support. It was shown that organizations adopt social enterprise to create needed revenue and yet the approach 
comes with challenges. First, social enterprise is an ill defined field creating the risk that it may be a passing fad. In addition, those who administer social enterprises must live in, and balance the two worlds of maximizing profit while maximizing social contributions. In addition, social enterprises must face significant legal barriers, including legal organizational structure, causing some states to create a new form of organization known as the low profit limited liability company or L3C. Finally, leaders must deal with the complexity of managing an organization with all the complexities of both the business and nonprofit world combined. Yet, in spite of these significant challenges the literature shows that there are organizations such as the Central Piedmont Community College Service Corp and the Cristo Rey network that are successfully integrating social enterprise based techniques into their operations, and in doing so are creating great benefit for students. While limited research has been done into the attitudes of school leaders toward these types of revenue generation approaches at the public school, none have fully integrated the social enterprise paradigm, nor have any of them addressed this challenge within the context of evangelical Christian schools. To this end this study represents a significant contribution to the existing literature on Christian school finance. 


\section{Chapter Three: Methodology}

For the purpose of this study, a single page, double-sided survey was distributed to a total of 104 school administrators and board presidents / chairmen at a total of 52 schools claiming affiliation with the Association of Christian Schools International (ACSI), located in the mid-America region as categorized by ACSI, and claiming an enrollment in excess of 300 students. All questions requested a response on an anchored numerical rating scale. The purpose of the survey was to determine the degree to which school leaders were currently employing basic social enterprise activities within their school and the degree to which they and their boards of directors were expected to be interested in participating in a variety of social enterprise based fund raising approaches if the opportunity were to present itself. The survey was mailed with a simple one page cover letter and an additional handwritten yellow post-it note thanking each individual by name for their time. Envelopes were hand addressed and contained a self addressed stamped envelope. All nonresponders as well as those school leaders who were missed in the first round of mailings were contacted via fax with a copy of the survey.

\section{Rationale for the Method}

Questionnaires are one of the six basic methods of data collection used by researchers (Johnson \& Christensen 2008). As with any method of data collection, questionnaires have their strengths and weaknesses. One of the strengths of a questionnaire is that it allows for the easy assessment of the opinions and attitudes of a 
group of people on several variables related to a topic. It also allows for conclusions to easily be drawn relative to probability of various truths (Hartas 2010; Check \& Schutt 2011). In this case, the ability to easily gather data relative to opinions and attitudes and determine probabilities fits well with the purpose of the research. This study has three primary research questions each of which fit well with a questionnaire based research design.

The first research question is the degree to which ACSI Christian school administrators and board members at relatively larger Christian schools in the ACSI MidAmerica region are interested in exploring social enterprise based solutions to their funding challenges. The questionnaire design allows for reasonable ease in assessing this by allowing for a relatively large sample of these administrators to be polled on their interest in a variety of very specific and yet representative potential applications of social enterprise to Christian school funding (Vogt, Gardner, \& Haeffele 2012).

The second research question is what specific areas, if any, of social enterprise are these Christian school administrators interested in exploring? The questionnaire is again an excellent fit for this in its ability to allow for the population to be polled on a variety of sample applications for social enterprise in the Christian school context. Each potential application provides representative information showing the interest of respondents in general applications of social enterprise based approaches to the Christian school context. Much can be learned about the attitudes of Christian school administrators toward one application vs. another by analyzing the patterns existent in what forms of social enterprise administrators were and were not interested in. This allows a probability 
assessment to then be made as to the likelihood that the rest of the population (non responders) will also be interested in each approach (Hartas 2010; Check \& Schutt 2011).

The final research question is the degree to which administrators and board members will agree or disagree on the application of social enterprise in the Christian school setting. The use of a questionnaire based design allows for numerical responses that are easily analyzed for both correlations and differences within a group (Boudah 2010). Thus, the use of a questionnaire based design allows for easy comparison of quantitative responses across a variety of groups (Check \& Schutt 2011). The answers to these questions will provide a plethora of data for those who may be interested in approaching school administrators regarding the use of social enterprise based approaches to fundraising. Often, knowing the right person to talk to is the key to the success of any proposal and the responses obtained in answering this third research question help to shed light on the best party to initially approach with a proposal.

\section{Population of the Study}

The survey included board presidents or chairmen and chief administrators in all ACSI affiliated schools with an enrollment greater than 300 and located in the MidAmerica region. The choice was made to focus on schools affiliated with the Association of Christian Schools International (ACSI) due to the relative size of this organization and the influence that their schools have on Christian education around the country. The survey was limited to a single region, in this case the Mid-America region, in order to allow for reasonable follow-up with non responders to create a sufficient response rate 
while maintaining a broad enough scope to be able to provide data with meaning to a reasonably large group of schools and stakeholders.

Within ACSI Christian schools in the Mid-America region, only schools with an enrollment of 300 or greater were included in this study. The reason for this is the relatively greater applicability of social enterprise to a larger school. Involvement in social enterprise at a large scale requires resources that a small school simply may not have.

While future studies may determine the degree to which information gained in this study can be generalized to other areas of the country, no attempt is being made in this study to do so. Results are only being generalized to ACSI Christian schools in the Mid-America region with enrollments greater than 300. Results from respondents are being generalized to non responders, but this is the extent to which the results are being generalized.

\section{Procedure}

Within the questionnaire or survey based approach to research design there are at least five potential approaches that can be taken (Check \& Schutt 2011). For the purpose of this study, a mail survey was chosen. The use of a mail survey allows for a broadly scattered population to be easily studied and tends to result in more consistent and generally higher response rates (Hartas 2010; Converse, Wolfe, Huang, \& Oswald 2008; Rooke, Le, Littlejohn, \& Dillman 2012). Thus, administrators and board members from across the Mid-America region can be easily analyzed where a face to face approach would not be practical. In designing this survey a telephone based approach was 
also considered due to the potential for an increased response rate. However, this approach was rejected due to the potential challenge of contacting board presidents. Board presidents will generally not be present at the school site and secretaries are generally hesitant to provide their contact information. In administering the survey some secretaries were even unwilling to provide the name of their board president forcing a few of the surveys to have to be addressed by title rather than name. In addition, the possibility of an e-mail or web based survey was rejected due to potential problems with response rate (Nulty 2008; Converse, Wolfe, Huang \& Oswald 2008).

In a mail based survey, one of the greatest threats to validity is response rate (Check \& Schutt 2011; Vogt, Gardner, \& Haeffele 2012). Six particular steps were taken to improve response rates for this survey. The first was the use of a self-addressed stamped envelope with an actual stamp as opposed to a return mail label included with the first wave of surveys. Research suggests that this can increase response rates presumably because of both the greater ease of response and the law of reciprocity which encourages individuals to respond rather than waste the financial outlay of the surveyor in purchasing the stamp (Lavelle, Todd, \& Campbell 2008). The second step that was taken was the use of follow up with all non responders. Check \& Schutt (2011) argue that this is the most important step a survey researcher can take to increase response rate. Follow up was conducted using faxed copies of the survey. Use of a multimode approach has been suggested by some research to increase response rates (Converse, Wolfe, Huang, \& Oswald 2008; Kroth et. al. 2009). In addition, initial surveys were hand addressed. Research suggests that this step can produce a small but consistent improvement in response rate (Choudhury, Hussain, Parsons, Rahman, Eldridge, \& 
Underwood 2012; Edwards et. al. 2009). Next, survey length was controlled to 1 front and back page to increase response rate (Shalqvist, Yena, Bull, Adams \& Preston 2011). Finally, surveys were mailed with an attached personalized sticky note thanking respondents for their time (Garner 2005; Cowie, Myfanwy \& Gulliford 2011).

A final choice that was made in the design of this study was the choice of an anchored numerical Likert scale in designing the survey. This approach works well when gauging the degree to which a survey taker agrees or disagrees with a statement or in this case a particular approach to the application of social enterprise to the Christian school setting (Vogt, Gardner, Haeffele 2012). It also allows for ease of quantitative calculations and supported the objective of keeping the survey short to increase response rate. For each of these reasons the use of an anchored numerical scale was the most appropriate design for this survey.

In approaching this study, ethical risks were minimal. Historically, the limitations for ethical research were first established in the Belmont Report of 1979 and later codified in the Code of Federal Regulations for the Protection of Human Subjects. These two documents contain principles for ethical research when human subjects are involved. These standards include informed consent, controlled risk, equitable selection of subjects, privacy, and confidentiality where appropriate (Springer 2009). Of these, the only risks affecting this study are coercion and confidentiality. While small steps were taken to encourage survey response, none cross the threshold of being unethically coercive. In addition, names of respondents and their data were made available only to the researcher and his assistants. In this way this study did not violate any principle of ethical research. In working with any form or research, the effective analysis of the data is just as 
important as the gathering of the data. In approaching data analysis for this study, several key objectives were considered. The first objective was to show the validity of the data gathered. In this case, this includes looking at validity from two angles. The first is ensuring that an adequate response rate has been achieved. In doing so several sources were consulted. While needed response rate does vary with sample size and the degree to which the data is being generalized the literature seems to suggest a general acceptance of 50\% as an adequate response rate (Nulty 2008; Vogt, Gardner \& Haeffele 2012; Check \& Schutt 2011). In addition to achieving an adequate response rate, correlation was measured between all variables including response method (mail vs. fax) and response wave (initial responders vs. those who responded after a reminder was sent). To easily measure this, the statistical software SPSS was used to create a correlation matrix showing any potential correlation between all possible combinations of set variables. This was the simplest way to insure no correlation existed between a confounding variable and the survey results.

In addition to analyzing for validity, analysis was set up with the intent of answering the three primary research questions for this study which have already been noted. The first and second research questions asked whether Christian school administrator and board presidents in the Mid-America region had an interest in exploring social enterprise based solutions to their funding challenges both in general and by specific potential applications. Several measures of descriptive statistics were analyzed and notated in chapters four and five of this study for the purpose of answering this question. These measures include: mean, maximum and minimum. Frequency tables were also constructed which showed both overall trends and illustrated the level of 
dispersion. In addition to analyzing each question separately, totals were calculated for all parts of the survey and then analyzed using the previously mentioned measures of central tendency. Finally, in analyzing four of the scenarios, schools who reported no current involvement in the given activity were isolated and separate frequency tables were constructed to show the level of interest on the part of the leaders of these schools in exploring new forms of social enterprise based funding solutions.

In answering the third research question, which asked about the degree to which board members differed from the views of lead administrators, a one-way analysis of variance was conducted between mean responses in each of the four categories on the survey: administrators, board presidents, administrators' view of what the attitude of the rest of the board would be, and board presidents' view of what the attitude of the rest of the board would be for each question as well as for the survey total. The one-way analysis of variance allows the researcher to determine if there is a statistically significant level of variance between these means based on which of these four categories they fall into. Thus the third research question was answered. 


\section{Chapter 4: Results}

The statistical analysis of the data from this research can be broadly grouped into four categories. The first deals with the measure of the validity of the data collected. The second deals with broad trends observed and answers the first research question of whether Christian school administrators as a whole are interested in exploring social enterprise to fund their schools. The third category goes into more depth, looking at each question from the survey instrument to shed more light on the first research question and answer the second research question of whether there are specific forms of social enterprise that interest school leaders more than others. The final section deals with any variance between responses from school administrators and responses from school board presidents or chairmen to answer the third and final research question of whether position within the school is a determining factor when looking at interest in social enterprise.

\section{Data Validity}

In examining the validity of the data, the researcher started by analyzing response rates. The overall response rate for this survey was $58.7 \%$ with a total of 61 surveys returned (one of which was excluded from the data set to prevent potential error) out of the 104 that were distributed. The majority of surveys were distributed by mail with a minimal number being distributed by fax. The response rate for surveys distributed by mail only was $61.5 \%$ with 91 surveys being initially distributed by mail and 56 being returned. The response rate for surveys initially distributed by fax was $38.5 \%$ with 13 surveys being distributed using this method and 5 being returned. The overall response 
rate is sufficient for this study given that the data is not being broadly generalized beyond the original survey population.

All data was also analyzed using one way analysis of variance (ANOVA) to insure that the original method of survey distribution, whether the responder replied on the first or second wave and the form in which the reply came (mail vs. fax), were not confounding variables. ANOVA testing failed to show a statistically significant degree of variance $(\mathrm{p}<.05)$ between the means for responders to the first wave vs. the second wave within the overall means for the three primary categories of current practices, the responder's views, and the views the responder expected their governing board to have. This suggests that overall current practices of social enterprise and openness to social enterprise based fund raising remained relatively stable across the two waves of survey responses.

Further ANOVA testing failed to show any statistically significant $(\mathrm{p}<.05)$ difference between the overall means for each of the previously mentioned categories based on the method of survey response. This suggests that survey recipients returning their survey by fax were statistically similar to those returning their survey by postal mail and adds to the confidence the researcher is able to have in the validity of the results.

The final ANOVA test analyzed survey results for statistically significant $(\mathrm{p}<.05)$ differences based on the method by which the original survey was distributed. The overall means for each category were analyzed and the method by which the original survey was distributed also failed to produce any statistically significant variance.

The combination of a reasonable response rate and these three rounds of ANOVA 
testing provide the researcher with the confidence to move forward in drawing statistical conclusions from this data set.

\section{General Trends}

In examining general trends within the data, the researcher sought to answer the first research question of whether or not Christian school leaders are open to social enterprise to enhance their overall fiscal standing. The first measure used in examining this was the overall mean for the eleven questions related to current social enterprise involvement that were posed on the survey. The mean for this category was 1.80 . This suggests that most Christian schools surveyed fell between no involvement in social enterprise based fund raising approaches and modest involvement with schools leaning closer to the no involvement side. As shown in table 1, the frequency distribution tells a similar story with only $1.7 \%$ of responders having an overall mean involvement rating of greater than modest involvement. All of this supports a conclusion that schools are currently only using this approach minimally if at all.

Table 1

Overall Current Involvement

\begin{tabular}{llllll}
\hline & & Frequency & Percent & Valid Percent & $\begin{array}{c}\text { Cumulative } \\
\text { Percent }\end{array}$ \\
\hline & $1-1.5$ & 16 & 26.7 & 26.7 & 26.7 \\
& $1.5-2$ & 28 & 46.7 & 46.7 & 73.3 \\
Valid & $2-2.5$ & 12 & 20.0 & 20.0 & 93.3 \\
& $2.5-3$ & 3 & 5.0 & 5.0 & 98.3 \\
& $3+$ & 1 & 1.7 & 1.7 & 100.0 \\
\multicolumn{7}{l}{ Tote. 1 = No Involvement 3=Modest Involvement 5=This activity has become a } \\
part of our school culture. Ranges are inclusive of the upper cut point and \\
exclusive of the lower point to avoid overlap.
\end{tabular}


The second section of the research was designed to indicate the degree to which the survey respondent was interested in applying social enterprise based funding techniques in his / her school. A total of nine scenarios were proposed with the intent of operationalizing the concept of social enterprise as it applies to the Christian school context. The overall mean of 2.61 suggests that, on the whole, Christian school administrators would cautiously place themselves around the somewhat interested category, but are not overly enthusiastic about the idea of social enterprise. Scores did however range from a minimum of 0 to a maximum of 4.11 indicating a broad range of interest levels with some administrators being strongly opposed while others are cautiously interested. As shown in table 2, a total of $26.7 \%$ of respondents had a mean interest level greater than somewhat interested.

Table 2

Overall Interest

\begin{tabular}{llllll}
\hline & & Frequency & Percent & $\begin{array}{r}\text { Valid } \\
\text { Percent }\end{array}$ & $\begin{array}{c}\text { Cumulative } \\
\text { Percent }\end{array}$ \\
\hline \multirow{6}{*}{ Valid } & $1-1.5$ & 2 & 3.3 & 3.3 & 3.3 \\
& $1.5-2$ & 8 & 13.3 & 13.3 & 16.7 \\
& $2-2.5$ & 18 & 30.0 & 30.0 & 46.7 \\
& $3-3-3$ & 16 & 26.7 & 26.7 & 73.3 \\
& $3.5-4$ & 4 & 15.0 & 15.0 & 88.3 \\
& $4+$ & 3 & 6.7 & 6.7 & 95.0 \\
& Total & 60 & 5.0 & 5.0 & 100.0 \\
\hline
\end{tabular}

Note. $1=$ Strongly opposed $3=$ Somewhat interested in considering, but would want to do some research $5=$ This sounds very exciting and I would be very interested.

The final section of the research analyzed the degree to which respondents, some of whom were administrators and other who were board chairmen or presidents, thought 
that their governing board would be interested in exploring each of the nine scenarios.

Interestingly this number was just slightly lower with an overall mean of 2.41 . This suggests that on the whole governing boards are expected to be quite cautious about applying social enterprise based funding techniques to their schools. The variance within this figure was again worth noting with a range of 4 and a standard deviation of .75. As shown in table 3 , a notable minority of $16.7 \%$ of school boards were expected to be more than somewhat interested in social enterprise based funding approaches.

Table 3

Overall Expected Board Interest

\begin{tabular}{rlllll}
\hline & Frequency & Percent & $\begin{array}{r}\text { Valid } \\
\text { Percent }\end{array}$ & $\begin{array}{c}\text { Cumulative } \\
\text { Percent }\end{array}$ \\
\hline & $1-1.5$ & 5 & 8.3 & 8.3 & 8.3 \\
$1.5-2$ & 10 & 16.7 & 16.7 & 25.0 \\
$2-2.5$ & 19 & 31.7 & 31.7 & 56.7 \\
Valid & $2.5-3$ & 16 & 26.7 & 26.7 & 83.3 \\
& $3-3.5$ & 6 & 10.0 & 10.0 & 93.3 \\
$3.5+$ & 4 & 6.7 & 6.7 & 100.0 \\
& Total & 60 & 100.0 & 100.0 & \\
\hline
\end{tabular}

Note. $1=$ Strongly opposed $3=$ Somewhat interested in considering, but would want to do some research $5=$ This sounds very exciting and I would be very interested.

\section{Item Analysis}

In light of these general trends, further analysis was done to determine the degree to which Christian school leaders desire to explore specific elements of social enterprise. This is in line with the second research question which asks about differences within the data by individual element of social enterprise. 
The first question that was asked in the survey was the degree to which schools currently had school materials, facilities, or events with corporate sponsors who provide the school with either financial income or in kind services in exchange for being named as a sponsor. The mean response for this question of 2.47 came back a little below the rating of three that would have indicated an overall modest involvement. As shown in table 4 , a frequency distribution for these responses shows $53.3 \%$ of responders were either not doing this at all or had only very minor involvement. $30 \%$ were modestly involved in this practice and $16.7 \%$ were more than modestly involved.

Table 4

Current Sponsorships

\begin{tabular}{llllll}
\hline & & Frequency & Percent & Valid Percent & $\begin{array}{c}\text { Cumulative } \\
\text { Percent }\end{array}$ \\
\hline \multirow{4}{*}{ Valid } & 1 & 16 & 26.7 & 26.7 & 26.7 \\
& 2 & 16 & 26.7 & 26.7 & 53.3 \\
& 3 & 18 & 30.0 & 30.0 & 83.3 \\
& 4 & 4 & 6.7 & 6.7 & 90.0 \\
& 5 & 6 & 10.0 & 10.0 & 100.0 \\
& Total & 60 & 100.0 & 100.0 & \\
\hline
\end{tabular}

Note. 1 = No Involvement 3=Modest Involvement 5=This activity has become a part of our school culture.

Next, school leaders were asked about the degree to which they have exclusive agreements, allowing one or more companies exclusive marketing rights for their category of product or service within their school building, at school events, or in school materials in exchange for providing the school with financial income or in kind services. The mean response of 1.55 shows that very few schools are currently engaging in these types of agreements as the anchor for the scale for these responses equated a response of one with no involvement. As shown in table 5, the frequency distribution further 
supported this by showing $68.3 \%$ of respondents having no current involvement in this practice and $95 \%$ having only modest or less involvement.

\section{Table 5}

Current Exclusive Agreements

\begin{tabular}{llllll}
\hline & & Frequency & Percent & Valid Percent & $\begin{array}{c}\text { Cumulative } \\
\text { Percent }\end{array}$ \\
\hline \multirow{4}{*}{ Valid } & 1 & 41 & 68.3 & 68.3 & 68.3 \\
& 2 & 10 & 16.7 & 16.7 & 85.0 \\
& 3 & 6 & 10.0 & 10.0 & 95.0 \\
& 4 & 1 & 1.7 & 1.7 & 96.7 \\
& 5 & 2 & 3.3 & 3.3 & 100.0 \\
& Total & 60 & 100.0 & 100.0 & \\
\hline
\end{tabular}

Note. 1 = No Involvement 3=Modest Involvement 5=This activity has become a part of our school culture.

In a slightly related question, school leaders were asked about their involvement with corporately sponsored incentive programs for their students. One classic example of this would be the Book It program developed by Pizza Hut to encourage students to read while bringing new customers into their stores. Interestingly, responses were only slightly higher than those given for corporate sponsorships with a mean of 1.72 . This indicates that most schools are also not currently participating in these forms of incentive programs. As show in table 6, the frequency distribution for these responses was similar to that found in the previous scenario with $59.6 \%$ of respondents having no involvement and only $7 \%$ having more than a modest involvement. These programs are offered by a number of organizations, but whether due to a philosophical opposition on the part of Christian school leaders or a simple lack of interest, most Christian schools are not taking advantage of these opportunities. Further study would be needed to determine conclusively the reason for this. 
Table 6

Current Incentive Programs

\begin{tabular}{|c|c|c|c|c|c|}
\hline & & Frequency & Percent & Valid Percent & $\begin{array}{c}\text { Cumulative } \\
\text { Percent }\end{array}$ \\
\hline \multirow{6}{*}{ Valid } & 1 & 34 & 56.7 & 59.6 & 59.6 \\
\hline & 2 & 11 & 18.3 & 19.3 & 78.9 \\
\hline & 3 & 8 & 13.3 & 14.0 & 93.0 \\
\hline & 4 & 2 & 3.3 & 3.5 & 96.5 \\
\hline & 5 & 2 & 3.3 & 3.5 & 100.0 \\
\hline & Total & 57 & 95.0 & 100.0 & \\
\hline Missing & System & 3 & 5.0 & & \\
\hline Total & J & 60 & 100.0 & & \\
\hline
\end{tabular}

Next, schools were asked two questions about renting of space within their buildings. While it is true that some schools may not have the room to do this, with the current drop in enrollment experienced by many Christian schools due to the recession, the researcher expected that many schools would have additional square footage open that might be put to use by outside organizations. This question was broken down by renting of space to commercial organizations vs. renting of space to noncommercial interests. Predictably, it appears that only a very limited number of schools (mean of 1.78) are currently renting space to commercial ventures. However, the number for noncommercial ventures is higher (mean of 2.55), bordering on the level of modest involvement. As shown in tables 7 and 8 , a frequency distribution shows $66.7 \%$ of schools having no involvement in renting space to commercial parties and $45 \%$ of schools having no involvement in renting space to noncommercial entities. Similarly, $90 \%$ of schools rated their involvement in renting space to commercial parties as modest or less while $71.7 \%$ rated their rental of space to noncommercial parties as modest or 
less. A future study could explore the exact nature of these noncommercial organizations as it seems likely that many of them would be local church groups.

Table 7

Current Appropriation of Space for Commercial Use

\begin{tabular}{llllll}
\hline & & Frequency & Percent & Valid Percent & \multicolumn{1}{c}{$\begin{array}{c}\text { Cumulative } \\
\text { Percent }\end{array}$} \\
\hline \multirow{4}{*}{ Valid } & 1 & 40 & 66.7 & 66.7 & 66.7 \\
& 2 & 3 & 5.0 & 5.0 & 71.7 \\
& 3 & 11 & 18.3 & 18.3 & 90.0 \\
& 5 & 2 & 3.3 & 3.3 & 93.3 \\
& 5 & 4 & 6.7 & 6.7 & 100.0 \\
\hline
\end{tabular}

Note. 1 = No Involvement 3=Modest Involvement 5=This activity has become a part of our school culture.

Table 8

Current Appropriation of Space for Non-Commercial Use

\begin{tabular}{llllll}
\hline & & Frequency & Percent & Valid Percent & \multicolumn{1}{c}{$\begin{array}{c}\text { Cumulative } \\
\text { Percent }\end{array}$} \\
\hline \multirow{4}{*}{ Valid } & 1 & 27 & 45.0 & 45.0 & 45.0 \\
& 2 & 1 & 1.7 & 1.7 & 46.7 \\
& 3 & 15 & 25.0 & 25.0 & 71.7 \\
& 4 & 6 & 10.0 & 10.0 & 81.7 \\
& 5 & 11 & 18.3 & 18.3 & 100.0 \\
& Total & 60 & 100.0 & 100.0 & \\
\hline
\end{tabular}

Note. 1 = No Involvement 3=Modest Involvement 5=This activity has become a part of our school culture.

With modern technology comes additional opportunities for marketing. Many organizations have seized this opportunity in an effort to create symbiotic relationships with local schools; the most well known being the Channel One organization. Thus, the next question asked school leaders to rate their involvement in electronic marketing in which commercial ventures are allowed to market to students or families through use of the school's e-mail list, website, or other electronic media. Channel One was given as an 
example. This question produced the lowest score of the survey with a mean of only 1.15 . Of further interest is the maximum score of 3 indicating that no schools consider themselves to be more than modestly involved in this form of fund raising. As shown in table $9,88.3 \%$ of schools said that they were not involved at all. Thus, of the schools surveyed very few are involved in electronic marketing to raise funds for their school at all and those that are tend to have only limited involvement.

Table 9

Current Electronic Marketing

\begin{tabular}{llllll}
\hline & & Frequency & Percent & Valid Percent & $\begin{array}{c}\text { Cumulative } \\
\text { Percent }\end{array}$ \\
\hline \multirow{4}{*}{ Valid } & 1 & 53 & 88.3 & 88.3 & 88.3 \\
& 2 & 5 & 8.3 & 8.3 & 96.7 \\
& 3 & 2 & 3.3 & 3.3 & 100.0 \\
& Total & 60 & 100.0 & 100.0 & \\
\hline
\end{tabular}

Note. 1 = No Involvement $3=$ Modest Involvement $5=$ This activity has become a part of our school culture.

The most traditional form of social enterprise employed by schools is the standard fund raiser. Students have been knocking on doors selling candy bars since long before the nonprofit world coined the term social enterprise. Thus, when school leaders were asked about the degree to which students are encouraged to participate in sales of goods or services with a portion of the profit providing a financial benefit to the school or funding specific activities, the overall response was the highest provided for any of the questions asking about the current activities of schools (mean of 3.2). As shown in table 10 , only $13.6 \%$ of schools said that they had no involvement in this form of fund raising and $64.4 \%$ of schools rated their involvement as modest or greater. This is an extremely important finding in discussing the degree to which schools are philosophically open to 
the concept of commercial activity to help fund their school and will be discussed in more detail in chapter five.

Table 10

Current Traditional Fundraiser Involvement

\begin{tabular}{llllll}
\hline & & Frequency & Percent & Valid Percent & $\begin{array}{c}\text { Cumulative } \\
\text { Percent }\end{array}$ \\
& 1 & 8 & 13.3 & 13.6 & 13.6 \\
& 2 & 13 & 21.7 & 22.0 & 35.6 \\
Valid & 3 & 14 & 23.3 & 23.7 & 59.3 \\
& 4 & 7 & 11.7 & 11.9 & 71.2 \\
& 5 & 17 & 28.3 & 28.8 & 100.0 \\
& Total & 59 & 98.3 & 100.0 & \\
\cline { 2 - 5 } Missing & System & \multicolumn{5}{c}{1.7} \\
\hline \multicolumn{7}{l}{ Total } \\
Note. 1 = No Involvement 3=Modest Involvement 5=This activity has become a part of \\
our school culture.
\end{tabular}

With all of the pressures of the current economy, many organizations are looking to outsource operations that can be more efficiently completed by other organizations. In light of this, schools were asked about the degree to which specific educational functions of their school have been outsourced to a private company. Scores for this item (mean of 1.47) indicated that most schools are not privatizing any of their educational functions or are privatizing very little. The maximum score of 5 , however, indicates that select schools are very involved in this practice. As shown in table 11, the frequency distribution for this data further illuminates this issue, showing that $73.3 \%$ of schools report no involvement in privatizing educational functions with only $3.3 \%$ reporting heavy involvement. A comment on one survey noted that only their lunch program was privatized and so even the schools that do outsource elements of their operations may do so on a very limited basis. 
Table 11

Current Privatization

\begin{tabular}{llllll}
\hline & & Frequency & Percent & Valid Percent & \multicolumn{1}{c}{$\begin{array}{c}\text { Cumulative } \\
\text { Percent }\end{array}$} \\
\hline \multirow{4}{*}{ Valid } & 1 & 44 & 73.3 & 73.3 & 73.3 \\
& 2 & 8 & 13.3 & 13.3 & 86.7 \\
& 3 & 6 & 10.0 & 10.0 & 96.7 \\
& 5 & 2 & 3.3 & 3.3 & 100.0 \\
\hline
\end{tabular}

Note. 1 = No Involvement 3=Modest Involvement 5=This activity has become a part of our school culture.

The final three questions posed to schools relating to their current involvements dealt with three specific scenarios that line up closely with the way in which the nonprofit world employs social enterprise. The first question asked about the degree to which their school partners with or runs an ongoing commercial venture whose primary purpose is to provide funds for the school. The second question asked about whether the school produces materials which it sells at a profit to other entities and the final question asked about whether the school provides training opportunities beyond those offered to the primary student body for a profit. Existing practices in each of these areas were quite low with means scores of $1.47,1.27$, and 1.23 respectively. The third option resulted in the second lowest mean score of the survey, indicating that even those schools that are most involved in this consider their involvement to be modest. As shown in tables 12-14, frequency distributions for the results in these three categories lead to similar conclusions with $81.7 \%$ of respondents reporting no current involvement in running any form of ongoing commercial venture, $90 \%$ reporting no involvement in producing materials to sell at a profit and $81.7 \%$ reporting no involvement in providing training opportunities beyond the normal school day. 
Table 12

Current Ongoing Commercial Venture

\begin{tabular}{llllll}
\hline & & Frequency & Percent & Valid Percent & $\begin{array}{c}\text { Cumulative } \\
\text { Percent }\end{array}$ \\
\hline \multirow{4}{*}{ Valid } & 1 & 49 & 81.7 & 81.7 & 81.7 \\
& 2 & 3 & 5.0 & 5.0 & 86.7 \\
& 4 & 3 & 5.0 & 5.0 & 91.7 \\
& 5 & 4 & 1.7 & 1.7 & 93.3 \\
& Total & 60 & 6.7 & 6.7 & 100.0 \\
\hline
\end{tabular}

Note. $1=$ No Involvement $3=$ Modest Involvement $5=$ This activity has become a part of our school culture.

Table 13

Current Production and Sale of Materials

\begin{tabular}{llllll}
\hline & & Frequency & Percent & Valid Percent & \multicolumn{1}{c}{$\begin{array}{c}\text { Cumulative } \\
\text { Percent }\end{array}$} \\
\hline \multirow{4}{*}{ Valid } & 1 & 54 & 90.0 & 90.0 & 90.0 \\
& 2 & 1 & 1.7 & 1.7 & 91.7 \\
& 3 & 2 & 3.3 & 3.3 & 95.0 \\
& 4 & 1 & 1.7 & 1.7 & 96.7 \\
& 5 & 2 & 3.3 & 3.3 & 100.0 \\
& Total & 60 & 100.0 & 100.0 & \\
\hline
\end{tabular}

Note. $1=$ No Involvement $3=$ Modest Involvement $5=$ This activity has become a part of our school culture.

Table 14

Current Training Opportunities

\begin{tabular}{llllll}
\hline & & Frequency & Percent & Valid Percent & \multicolumn{1}{c}{$\begin{array}{c}\text { Cumulative } \\
\text { Percent }\end{array}$} \\
\hline \multirow{4}{*}{ Valid } & 1 & 49 & 81.7 & 81.7 & 81.7 \\
& 2 & 8 & 13.3 & 13.3 & 95.0 \\
& 3 & 3 & 5.0 & 5.0 & 100.0 \\
& Total & 60 & 100.0 & 100.0 & \\
\hline
\end{tabular}

Note. 1 = No Involvement 3=Modest Involvement 5=This activity has become a part of our school culture. 
While the data appears to reflect an overall weak current involvement in social enterprise for Christian school leaders, the bigger question is whether there are areas in which Christian school administrators are open to adding to their current practices. The next section of the survey instrument asked school leaders to respond to a total of nine potential scenarios that operationalized different elements of social enterprise relating to Christian schools. For each scenario leaders were asked to rate both their own interest and the interest they anticipated their school board would have.

The first scenario posed to school leaders involved starting a thrift store with a high percentage of the profit benefitting the school. This scenario represents an application of social enterprise that is relatively familiar to most Americans. Interest in this category fell just below the modest level (mean of 2.5) with a range from one extreme to the other. The mean for expected board interest of 2.32 was slightly lower than the mean for the responder indicating an expectation of overall caution on the part of the board to take on such an endeavor. As shown in table 15, the frequency distribution reflects the same overall trend with $77.6 \%$ of responses ranging from between strongly opposed and somewhat interested. However, it is worth noting that $22.4 \%$ of respondents expressed a significant interest in exploring this opportunity. Expected board interest was notably lower with only $10.1 \%$ expecting their board to be more than somewhat interested. This expected caution on the part of the board may be a part of the reason why the operation of a thrift store has not been proposed at some of these schools. Since school board members often come from the business world, they are acutely aware of the challenges inherent in running a business and may prefer to stay away from such an approach. 
Table 15

Interest in Thrift Store Operation

\begin{tabular}{|c|c|c|c|c|c|c|c|c|c|}
\hline & & \multicolumn{2}{|c|}{ Frequency } & \multicolumn{2}{|c|}{ Percent } & \multicolumn{2}{|c|}{ Valid \% } & \multicolumn{2}{|c|}{ Cumulative $\%$} \\
\hline & & $\mathrm{R}$ & $\mathrm{B}$ & $\mathrm{R}$ & $\mathrm{B}$ & $\mathrm{R}$ & $\mathrm{B}$ & $\mathrm{R}$ & $\mathrm{B}$ \\
\hline \multirow{6}{*}{ Valid } & 1 & 15 & 17 & 25.0 & 28.3 & 25.9 & 29.8 & 25.9 & 29.8 \\
\hline & 2 & 16 & 16 & 26.7 & 26.7 & 27.6 & 28.1 & 53.4 & 57.9 \\
\hline & 3 & 14 & 18 & 23.3 & 30.0 & 24.1 & 31.6 & 77.6 & 89.5 \\
\hline & 4 & 9 & 1 & 15.0 & 1.7 & 15.5 & 1.8 & 93.1 & 91.2 \\
\hline & 5 & 4 & 5 & 6.7 & 8.3 & 6.9 & 8.8 & 100.0 & 100.0 \\
\hline & Total & 58 & 57 & 96.7 & 95.0 & 100.0 & 100.0 & & \\
\hline Missing & System & 2 & 3 & 3.3 & 5.0 & & & & \\
\hline Total & & 60 & 60 & 100.0 & 100.0 & & & & \\
\hline \multicolumn{10}{|c|}{$\begin{array}{l}\text { Note. } 1=\text { Strongly opposed } 3=\text { Somewhat interested in considering, but would want to } \\
\text { do some research } 5=\text { This sounds very exciting and I would be very interested. }\end{array}$} \\
\hline $\mathrm{R}=\mathrm{Resp}$ & nt $B=B$ & & & & & & & & \\
\hline
\end{tabular}

The second scenario asks about providing supplemental services to a school's existing families that complement their mission. The examples of child care and tutoring were given to help leaders accurately picture this. School leaders seemed more open to this than most scenarios. The overall mean for both the interest of the respondent (3.66) and anticipated overall board interest (3.45) exceeds the threshold for being somewhat interested with table 16 showing $54.2 \%$ of respondents indicating that they were greater than somewhat interested or even excited about this idea and $48.2 \%$ saying that they expected the same for their board. Similarly, the number of respondents either strongly objecting or mildly objecting was notably low with only $15.3 \%$ of respondents stating that they were less than somewhat interested and only $23.2 \%$ of school boards expected to be less than somewhat interested. This favorable response indicates that these types of programs are seen favorably by Christian school leaders. 
Table 16

Interest in Providing Supplemental Services

\begin{tabular}{|c|c|c|c|c|c|c|c|c|c|c|}
\hline & & \multicolumn{3}{|c|}{ Frequency } & \multicolumn{2}{|c|}{ Percent } & \multicolumn{2}{|c|}{ Valid \% } & \multicolumn{2}{|c|}{ Cumulative $\%$} \\
\hline & & $\mathrm{R}$ & B & & $\mathrm{R}$ & B & $\mathrm{R}$ & B & $\mathrm{R}$ & B \\
\hline \multirow{6}{*}{ Valid } & 1 & 2 & & 4 & 3.3 & 6.7 & 3.4 & 7.1 & 3.4 & 7.1 \\
\hline & 2 & 7 & & 9 & 11.7 & 15.0 & 11.9 & 16.1 & 15.3 & 23.2 \\
\hline & 3 & 18 & & 16 & 30.0 & 26.7 & 30.5 & 28.6 & 45.8 & 51.8 \\
\hline & 4 & 14 & & 12 & 23.3 & 20.0 & 23.7 & 21.4 & 69.5 & 73.2 \\
\hline & 5 & 18 & & 15 & 30.0 & 25.0 & 30.5 & 26.8 & 100.0 & 100.0 \\
\hline & Total & 59 & & 56 & 98.3 & 93.3 & 100.0 & 100.0 & & \\
\hline Missing & System & 1 & 4 & & 1.7 & 6.7 & & & & \\
\hline Total & & 60 & 60 & & 100.0 & 100 & & & & \\
\hline
\end{tabular}

The next scenario further develops the second scenario by asking leaders the degree to which they would be interested in providing the same services noted in scenario two to families from outside their current student body some of whom may not come from a Christian background. While there was still a degree of openness to this, there was a notable drop in positive responses compared with the responses to the second scenario. Leaders seemed less interested in providing services to families that are not a part of their student body. The overall mean score of 2.86 for responder interest and 2.53 for anticipated board interest indicates an average interest of slightly less than somewhat interested. As shown in table 17, the frequency distribution tells a similar story with only $28.8 \%$ of respondents expressing an interest greater than somewhat interested and only $19 \%$ expecting their board to be more than somewhat interested. This number still indicates some interest in this type of opportunity but is notably low in comparison to the previous response. 
Table 17

Interest in Providing Supplemental Services to an Outside Audience

\begin{tabular}{|c|c|c|c|c|c|c|c|c|c|}
\hline & & \multicolumn{2}{|c|}{ Frequency } & \multicolumn{2}{|c|}{ Percent } & \multicolumn{2}{|c|}{ Valid \% } & \multicolumn{2}{|c|}{ Cumulative $\%$} \\
\hline & & $\mathrm{R}$ & B & $\mathrm{R}$ & B & $\mathrm{R}$ & B & $\mathrm{R}$ & B \\
\hline \multirow{6}{*}{ Valid } & 1 & 10 & 16 & 16.7 & 26.7 & 16.9 & 27.6 & 16.9 & 27.6 \\
\hline & 2 & 15 & 12 & 25.0 & 20.0 & 25.4 & 20.7 & 42.4 & 48.3 \\
\hline & 3 & 17 & 19 & 28.3 & 31.7 & 28.8 & 32.8 & 71.2 & 81.0 \\
\hline & 4 & 7 & 5 & 11.7 & 8.3 & 11.9 & 8.6 & 83.1 & 89.7 \\
\hline & 5 & 10 & 6 & 16.7 & 10.0 & 16.9 & 10.3 & 100.0 & 100.0 \\
\hline & Total & 59 & 58 & 98.3 & 96.7 & 100.0 & 100.0 & & \\
\hline Missing & System & 1 & 2 & 1.7 & 3.3 & & & & \\
\hline Total & & 60 & 60 & 100.0 & 100.0 & & & & \\
\hline
\end{tabular}

The fourth scenario is similar to the third in that it involves offering educational services beyond the school's student body, but the focus for this scenario is on adults from local churches with the specific example of teacher training for Sunday School teachers being given. The scenario specified that these would be classes offered by existing faculty members through the use of supplemental contracts. Interest in this was slightly lower than the interest in offering more child focused services beyond the student body with a mean of 2.56 for responder interest and 2.36 for expected board interest. As shown in table 18, frequency distribution shows $76.3 \%$ of respondents giving ratings ranging from strongly opposed to somewhat interested with only $23.7 \%$ giving ratings greater than somewhat interested and only $13.7 \%$ of school boards expected to share that same level of enthusiasm. This response again shows most school leaders to be disinterested, but a significantly large population who are interested to warrant further study. 
Table 18

Interest in Providing Classes to Adults from Local Churches

\begin{tabular}{|c|c|c|c|c|c|c|c|c|c|}
\hline & & & ency & & cent & & $\operatorname{lid} \%$ & Cum & ative $\%$ \\
\hline & & $\mathrm{R}$ & B & $\mathrm{R}$ & B & $\mathrm{R}$ & B & $\mathrm{R}$ & B \\
\hline & 1 & 18 & 17 & 30.0 & 28.3 & 30.5 & 29.3 & 30.5 & 29.3 \\
\hline & 2 & 15 & 17 & 25.0 & 28.3 & 25.4 & 29.3 & 55.9 & 58.6 \\
\hline Volid & 3 & 13 & 17 & 21.7 & 28.3 & 22.0 & 29.3 & 78.0 & 87.9 \\
\hline vand & 4 & 5 & 4 & 8.3 & 6.7 & 8.5 & 6.9 & 86.4 & 94.8 \\
\hline & 5 & 8 & 3 & 13.3 & 5.0 & 13.6 & 5.2 & 100.0 & 100.0 \\
\hline & Total & 59 & 58 & 98.3 & 96.7 & 100.0 & 100.0 & & \\
\hline Missing & System & 1 & 2 & 1.7 & 3.3 & & & & \\
\hline Total & & 60 & 60 & 100.0 & 100.0 & & & & \\
\hline
\end{tabular}

Furthermore, the frequency distribution excluding all schools who are currently already offering adults classes to some degree, as displayed in table 19 , shows $22.9 \%$ of respondents not currently involved in this practice more than somewhat interested in considering it. Interest among board members was expected to be lower with only $12.8 \%$ expected to be more than somewhat interested. This finding adds validity to the conclusion that there is a significant interest among school leaders not currently offering classes to adults in exploring this opportunity. While it is true that the majority of school leaders were somewhat interested or less in this approach, a very significant minority of almost one fourth of Christian school leaders would like to explore this and are energized by the idea. The key in examining this further will be to determine whether the anticipated gap between respondent interest and anticipated board interest reflects the reality of the views held by Christian school board members. 
Table 19

Interest in Providing Classes to Adults where no Current Involvement Exists

\begin{tabular}{|c|c|c|c|c|c|c|c|c|c|}
\hline & & \multicolumn{2}{|c|}{ Frequency } & \multicolumn{2}{|c|}{ Percent } & \multicolumn{2}{|c|}{ Valid \% } & \multicolumn{2}{|c|}{ Cumulative $\%$} \\
\hline & & $\mathrm{R}$ & $\mathrm{B}$ & $\mathrm{R}$ & B & $\mathrm{R}$ & $\mathrm{B}$ & $\mathrm{R}$ & $\mathrm{B}$ \\
\hline \multirow{6}{*}{ Valid } & 1 & 16 & 14 & 32.7 & 28.6 & 33.3 & 29.8 & 33.3 & 29.8 \\
\hline & 2 & 12 & 14 & 24.5 & 28.6 & 25.0 & 29.8 & 58.3 & 59.6 \\
\hline & 3 & 9 & 13 & 18.4 & 26.5 & 18.8 & 27.7 & 77.1 & 87.2 \\
\hline & 4 & 4 & 3 & 8.2 & 6.1 & 8.3 & 6.4 & 85.4 & 93.6 \\
\hline & 5 & 7 & 3 & 14.3 & 6.1 & 14.6 & 6.4 & 100.0 & 100.0 \\
\hline & Total & 48 & 47 & 98.0 & 95.9 & 100.0 & 100.0 & & \\
\hline Missing & System & 1 & 2 & 2.0 & 4.1 & & & & \\
\hline Total & & 49 & 49 & 100.0 & 100.0 & & & & \\
\hline \multicolumn{10}{|c|}{$\begin{array}{l}\text { Note. } 1=\text { Strongly opposed } 3=\text { Somewhat interested in considering, but would want to } \\
\text { do some research } 5=\text { This sounds very exciting and I would be very interested. }\end{array}$} \\
\hline \multicolumn{10}{|c|}{$\mathrm{R}=$ Respondent $\mathrm{B}=\mathrm{Board}$} \\
\hline
\end{tabular}

Scenario five further develops this concept of offering services to local churches by asking school leaders about their level of interest in developing curriculum materials to be used by local churches and / or other Christian schools. The scenario notes that this may involve the addition of extra faculty members if all goes well. Responses to this scenario were similar to those for scenario four although just slightly higher with mean scores of 2.66 for respondent interest and 2.36 for anticipated board interest. The overall mean is again just below the somewhat interested level, but of great interest are two frequency distributions drawn from the data. Table 20 display that based on the full population, the frequency distribution shows $27.1 \%$ of respondents being more than somewhat interested and $19.3 \%$ of school boards expected to be more than somewhat interested in this approach. 
Table 20

Interest in Creating Curriculum for Local Churches or Other Christian Schools

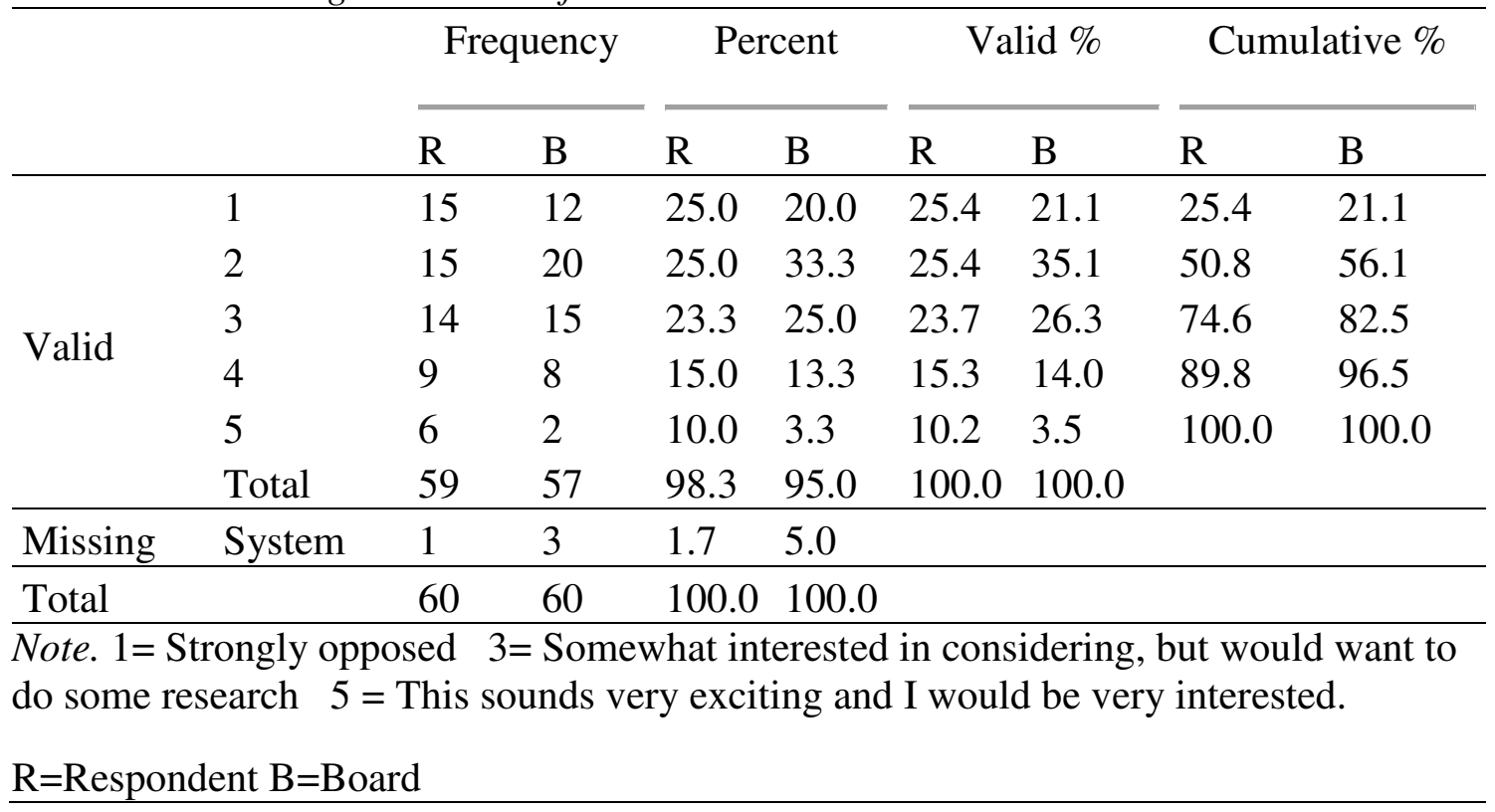

In addition, when the frequency distribution only includes cases where there is no current involvement in creating materials for outside organizations as shown in table 21 , the new interest in creating materials for churches and other schools is clearly shown with $24.5 \%$ of respondents who schools were not currently producing these materials stating that they are more than somewhat interested in exploring this opportunity. Like the results for offering adult classes, these results show a significant minority significantly interested in exploring the opportunity to create curriculum for local churches or other Christian schools. Notably, anticipated board interest was again lower than respondent interest with $17.6 \%$ of board members expected to be more than somewhat interested in pursuing this type of opportunity. School board members were more often expected to be somewhat interested in this opportunity than enthusiastic. 
Table 21

Interest in Creating Curriculum for Local Churches or Other Christian Schools Where no Current Involvement Exists

\begin{tabular}{|c|c|c|c|c|c|c|c|c|c|}
\hline & \multicolumn{2}{|c|}{ Frequency } & \multicolumn{2}{|c|}{ Percent } & \multicolumn{2}{|c|}{ Valid \% } & \multicolumn{2}{|c|}{ Cumulative \% } \\
\hline & & $\mathrm{R}$ & B & $\mathrm{R}$ & B & $\mathrm{R}$ & B & $\mathrm{R}$ & B \\
\hline \multirow{6}{*}{ Valid } & 1 & 15 & 12 & 27.8 & 22.2 & 28.3 & 23.5 & 28.3 & 23.5 \\
\hline & 2 & 13 & 15 & 24.1 & 27.8 & 24.5 & 29.4 & 52.8 & 52.9 \\
\hline & 3 & 12 & 15 & 22.2 & 27.8 & 22.6 & 29.4 & 75.5 & 82.4 \\
\hline & 4 & 7 & 7 & 13.0 & 13.0 & 13.2 & 13.7 & 88.7 & 96.1 \\
\hline & 5 & 6 & 2 & 11.1 & 3.7 & 11.3 & 3.9 & 100.0 & 100.0 \\
\hline & Total & 53 & 51 & 98.1 & 94.4 & \multicolumn{2}{|c|}{$100.0 \quad 100.0$} & & \\
\hline Missing & System & 1 & 3 & 1.9 & \multicolumn{3}{|l|}{5.6} & & \\
\hline Total & & 54 & 54 & 100.0 & \multicolumn{3}{|l|}{100.0} & & \\
\hline
\end{tabular}

As in the questions regarding current social enterprise involvement, this section of the survey instrument also posed two questions related to renting of space to outside parties. The first involves renting of space outside of school hours. Interest was again slightly below the moderate level with a mean of 2.70 for respondents and 2.55 for expected board interest. Notably this seemed to be a fairly polarizing scenario with table 22 displaying $31.6 \%$ of respondents being strongly opposed to the idea while $33.3 \%$ were more than somewhat interested, and $28.6 \%$ of school boards expected to be more than somewhat interested with $32.1 \%$ expected to be strongly opposed. The polarized nature of these results again lend themselves well to future study to gain insight into the reasons why school leaders were either so strongly opposed or so greatly interested in this opportunity. 
Table 22

Interest in Renting Space out During Hours School is not in Session

\begin{tabular}{|c|c|c|c|c|c|c|c|c|c|}
\hline & \multicolumn{2}{|c|}{ Frequency } & \multicolumn{2}{|c|}{ Percent } & \multicolumn{2}{|c|}{ Valid \% } & \multicolumn{2}{|c|}{ Cumulative $\%$} \\
\hline & & $\mathrm{R}$ & B & $\mathrm{R}$ & B & $\mathrm{R}$ & B & $\mathrm{R}$ & B \\
\hline \multirow{6}{*}{ Valid } & 1 & 18 & 18 & 30.0 & 30.0 & 31.6 & 32.1 & 31.6 & 32.1 \\
\hline & 2 & 9 & 9 & 15.0 & 15.0 & 15.8 & 16.1 & 47.4 & 48.2 \\
\hline & 3 & 11 & 13 & 18.3 & 21.7 & 19.3 & 23.2 & 66.7 & 71.4 \\
\hline & 4 & 10 & 12 & 16.7 & 20.0 & 17.5 & 21.4 & 84.2 & 92.9 \\
\hline & 5 & 9 & 4 & 15.0 & 6.7 & 15.8 & 7.1 & 100.0 & 100.0 \\
\hline & Total & 57 & 56 & 95.0 & 93.3 & 100.0 & 100.0 & & \\
\hline Missing & System & 3 & 4 & 5.0 & 6.7 & & & & \\
\hline Total & & 60 & 60 & 100.0 & 100.0 & & & & \\
\hline \multicolumn{10}{|c|}{$\begin{array}{l}\text { Note. } 1=\text { Strongly opposed } 3=\text { Somewhat interested in considering, but would want to } \\
\text { do some research } 5=\text { This sounds very exciting and I would be very interested. }\end{array}$} \\
\hline \multicolumn{10}{|c|}{$\mathrm{R}=$ Respondent $\mathrm{B}=$ Board } \\
\hline
\end{tabular}

When all schools that are currently renting out space are eliminated, as displayed in table 23 , the interest level in exploring the option of renting out space in the future drops further with only $20 \%$ of respondents more than somewhat interested. Notably this number decreases significantly when looking at expected board interest with only $8.3 \%$ of board members expected to be more than somewhat interested in looking into this option. While further studies would be necessary to say with certainty what the reason for this is, it can be reasonably hypothesized that a number of these schools may simply not have space to rent out. Comments hand written in on a few surveys indicated that due to being located in a church they were not able to rent out space. In spite of the relatively low interest, it should be noted that there is again a significant minority of schools where school leaders are not currently renting out space after school but have a significant interest in doing so. 
Table 23

Interest in Renting Space out During Hours School is not in Session Where no Current Involvement Exists

\begin{tabular}{|c|c|c|c|}
\hline Frequency & Percent & Valid \% & Cumulative $\%$ \\
\hline B & B & B & B \\
\hline
\end{tabular}

\begin{tabular}{llllllllll}
\hline & 1 & 14 & 16 & 53.8 & 61.5 & 56.0 & 66.7 & 56.0 & 66.7 \\
& 2 & 4 & 5 & 15.4 & 19.2 & 16.0 & 20.8 & 72.0 & 87.5 \\
Valid & 3 & 2 & 1 & 7.7 & 3.8 & 8.0 & 4.2 & 80.0 & 91.7 \\
& 4 & 2 & 2 & 7.7 & 7.7 & 8.0 & 8.3 & 88.0 & 100.0 \\
& 5 & 3 & 24 & 11.5 & 92.3 & 12.0 & 100.0 & 100.0 & \\
& Total & 25 & 2 & 96.2 & 7.7 & 100.0 & & & \\
\hline Missing & System & 1 & 2 & 3.8 & 7.7 & & & & \\
\hline Total & & 26 & 26 & 100.0 & 100.0 & & & \\
\hline
\end{tabular}

Note. $1=$ Strongly opposed $3=$ Somewhat interested in considering, but would want to do some research $5=$ This sounds very exciting and I would be very interested.

$\mathrm{R}=$ Respondent $\mathrm{B}=$ Board

Scenario seven pushes the idea of space rental further to poll the interest of school leaders in renting out space within their facility during school hours. This involves the introduction of a number of additional potential complications and was thus not expected to be as popular. As a result, it was not surprising that this was the least popular of the scenarios polled with an interest level for both responders and anticipated board interest just higher than strongly opposed (mean of 1.61 and 1.39 respectively). As shown in table $24,69.6 \%$ of respondents noted that they were strongly opposed to this idea, with $75.9 \%$ of school boards expected to be strongly opposed. Only $10.5 \%$ of respondents were more than somewhat interested in this opportunity with only $7.3 \%$ of school boards expected to be interested. 
Table 24

Interest in Renting Space out During Hours School is in Session

\begin{tabular}{|c|c|c|c|c|c|c|c|c|c|}
\hline & & & uency & Per & cent & & $\operatorname{lid} \%$ & Cum & ative $\%$ \\
\hline & & $\mathrm{R}$ & B & $\mathrm{R}$ & B & $\mathrm{R}$ & B & $\mathrm{R}$ & B \\
\hline & 1 & 40 & 42 & 66.7 & 70.0 & 70.2 & 76.4 & 70.2 & 76.4 \\
\hline & 2 & 8 & 9 & 13.3 & 15.0 & 14.0 & 16.4 & 84.2 & 92.7 \\
\hline Volid & 3 & 3 & 0 & 5.0 & 0.0 & 5.3 & 0.0 & 89.5 & 92.7 \\
\hline vanda & 4 & 4 & 4 & 6.7 & 6.7 & 7.0 & 7.3 & 96.5 & 100.0 \\
\hline & 5 & 2 & 0 & 3.3 & 0.0 & 3.5 & 0.0 & 100.0 & 100.0 \\
\hline & Total & 57 & 55 & 95.0 & 91.7 & 100.0 & 100.0 & & \\
\hline Missing & System & 3 & 5 & 5.0 & 8.3 & & & & \\
\hline Total & & 60 & 60 & 100.0 & 100.0 & & & & \\
\hline
\end{tabular}

Furthermore, when schools with no current involvement in renting out space were isolated, as displayed in table 25 , only $8 \%$ of respondents were more than somewhat interested in exploring this option and none of the school boards were expected to be more than somewhat interested. The interest among board members where schools were not currently renting out space during school hours was expected to be so low that $87.5 \%$ were expected to be strongly opposed with the rest only giving a rating of 2 on a 5 point Likert scale to describe expected board interest. With interest in this category being relatively low for the population as a whole, it should not be surprising that interest among schools not currently renting out space at all would be nearly nonexistent with only $8 \%$ of respondents more than somewhat interested and none of the school boards expected to be even somewhat interested. 
Table 25

Interest in Renting Space out During Hours School is in Session Where no Current Involvement Exists

\begin{tabular}{|c|c|c|c|}
\hline Frequency & Percent & Valid \% & Cumulative \% \\
\hline B & B & B & $\mathrm{R}$ \\
\hline
\end{tabular}

\begin{tabular}{llllllllll}
\hline & 1 & 19 & 21 & 73.1 & 80.8 & 76.0 & 87.5 & 76.0 & 87.5 \\
& 2 & 2 & 3 & 7.7 & 11.5 & 8.0 & 12.5 & 84.0 & 100.0 \\
Valid & 3 & 2 & 0 & 7.7 & 0.0 & 8.0 & 0.0 & 92.0 & 100.0 \\
& 5 & 2 & 0 & 7.7 & 0.0 & 8.0 & 0.0 & 100.0 & 100.0 \\
& Total & 25 & 24 & 96.2 & 92.3 & 100.0 & 100.0 & & \\
\hline Missing & System & 1 & 2 & 3.8 & 7.7 & & & & \\
\hline Total & & 26 & 26 & 100.0 & 100.0 & & & \\
\hline
\end{tabular}

Note. $1=$ Strongly opposed $3=$ Somewhat interested in considering, but would want to do some research $5=$ This sounds very exciting and I would be very interested.

$\mathrm{R}=$ Respondent $\mathrm{B}=\mathrm{Board}$

The final two scenarios dealt with the direct or indirect promotion of commercial companies or their products or services to school families. The first scenario dealt with direct promotion either online or offline. Interest in this approach was far more focused on the lower end of the rating scale with a respondent mean score half way between strongly opposed and somewhat interested (2.05) and table 26 displaying $87.9 \%$ of responses falling in this range. Board caution in the area of product promotion was expected to be even stronger with a means score of 1.86 and a full $96.4 \%$ of school boards expected to fall between strongly opposed and somewhat interested. $42.9 \%$ were expected to be strongly opposed. This appears to be an area that most Christian school leaders would like to stay clear of with none of the school boards expected to look at this opportunity as exciting and a source of great interest. 
Table 26

Interest in Directly Promoting Products or Services

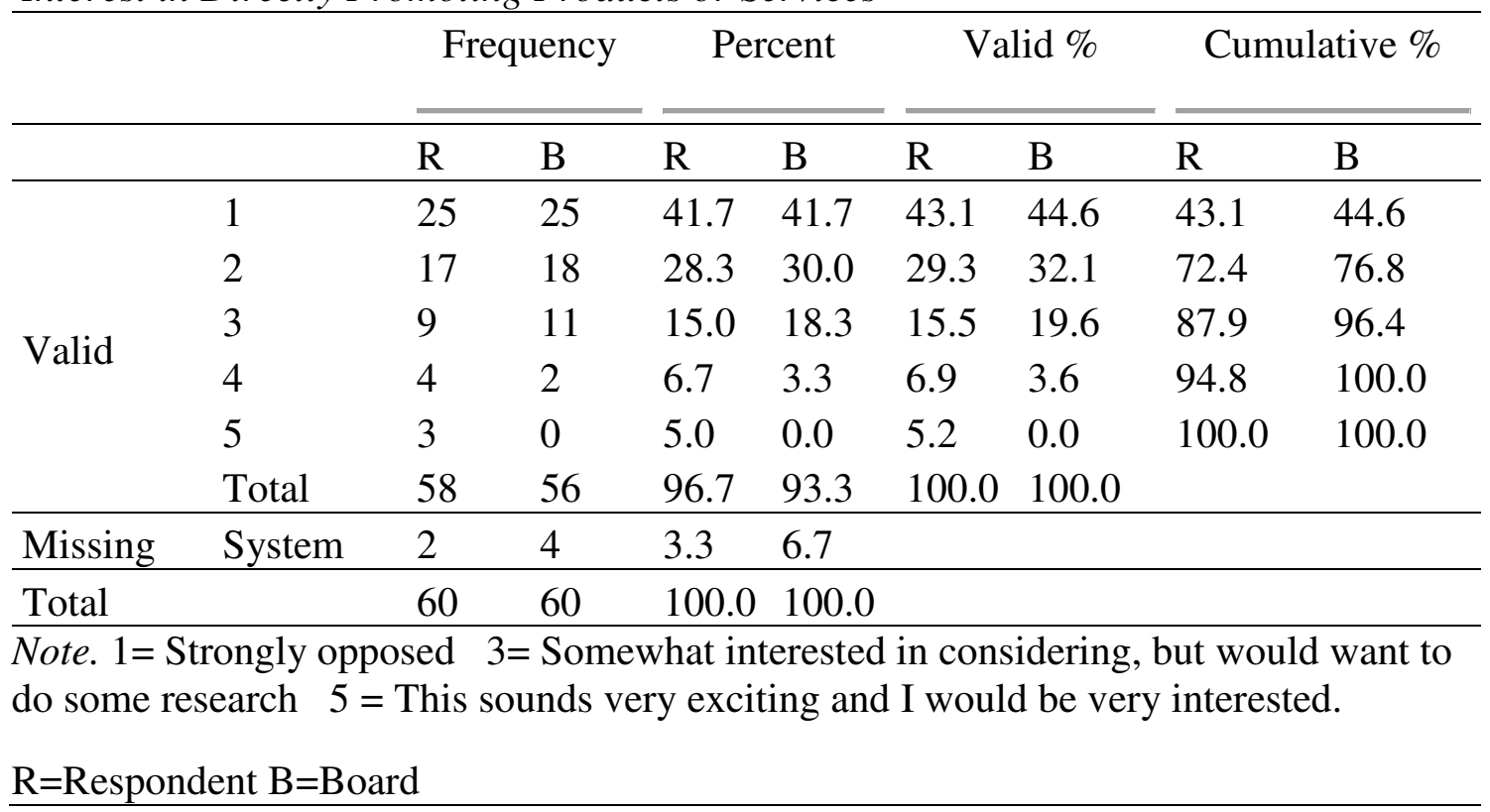

In light of the results to this last scenario, it was surprising how many schools were interested in a less direct promotion of companies and their products or services in the form of corporate sponsorships of educational facilities, materials, or events. This was one of the top two areas that schools were interested in with a mean score for both respondents (3.46) and anticipated board interest (3.51) showing a more than moderate interest in further exploring this area. As shown in table 27, 84.7\% of respondents said that they were at least somewhat interested in exploring this form of funding with $86 \%$ of school boards expected to be at least somewhat interested. Also notable was the low rate of objection to this form of commercialism with only $5.1 \%$ of respondents strongly opposed and only $5.3 \%$ of school board expected be strongly opposed to pursuing corporate sponsorships for their schools. Also important here is the expected level of unity in this interest between respondents and their school boards. 
Table 27

Interest in Corporate Sponsorships

\begin{tabular}{|c|c|c|c|c|c|c|c|c|c|}
\hline & & \multicolumn{2}{|c|}{ Frequency } & \multicolumn{2}{|c|}{ Percent } & \multicolumn{2}{|c|}{ Valid \% } & \multicolumn{2}{|c|}{ Cumulative $\%$} \\
\hline & & $\mathrm{R}$ & B & $\mathrm{R}$ & B & $\mathrm{R}$ & B & $\mathrm{R}$ & B \\
\hline \multirow{6}{*}{ Valid } & 1 & 3 & 3 & 5.0 & 5.0 & 5.1 & 5.3 & 5.1 & 5.3 \\
\hline & 2 & 7 & 6 & 11.7 & 10.0 & 11.9 & 10.5 & 16.9 & 15.8 \\
\hline & 3 & 23 & 23 & 38.3 & 38.3 & 39.0 & 40.4 & 55.9 & 56.1 \\
\hline & 4 & 14 & 11 & 23.3 & 18.3 & 23.7 & 19.3 & 79.7 & 75.4 \\
\hline & 5 & 12 & 14 & 20.0 & 23.3 & 20.3 & 24.6 & 100.0 & 100.0 \\
\hline & Total & 59 & 57 & 98.3 & 95.0 & 100.0 & 100.0 & & \\
\hline Missing & System & 1 & 3 & 1.7 & 5.0 & & & & \\
\hline Total & & 60 & 60 & 100.0 & 100.0 & & & & \\
\hline
\end{tabular}

Even more telling is the frequency distribution for schools that currently do not have any corporate sponsors. Table 28 displays that among this population $31.2 \%$ of respondents reported being more than somewhat interested in this opportunity. In a reversal from the pattern in most questions, expected board interest in corporate sponsorships where schools are not currently involved in this practice actually exceeds the interest of respondents. $35.7 \%$ of school boards were expected to be interested in exploring corporate sponsorships. This is significant for organizations who may have an interest in promoting such a practice among Christian schools. The survey results show that about one third of Christian schools who do not currently have any corporate sponsors are interested in having one. Similarly, while opposition to pursuing commercial sponsorships is naturally higher among schools not currently engaging in such practices, it is still somewhat low with only $18.8 \%$ of respondents strongly opposed and only $21.4 \%$ of school boards expected to be strongly opposed. 
Table 28

Interest in Corporate Sponsorships Where no Current Involvement Exists

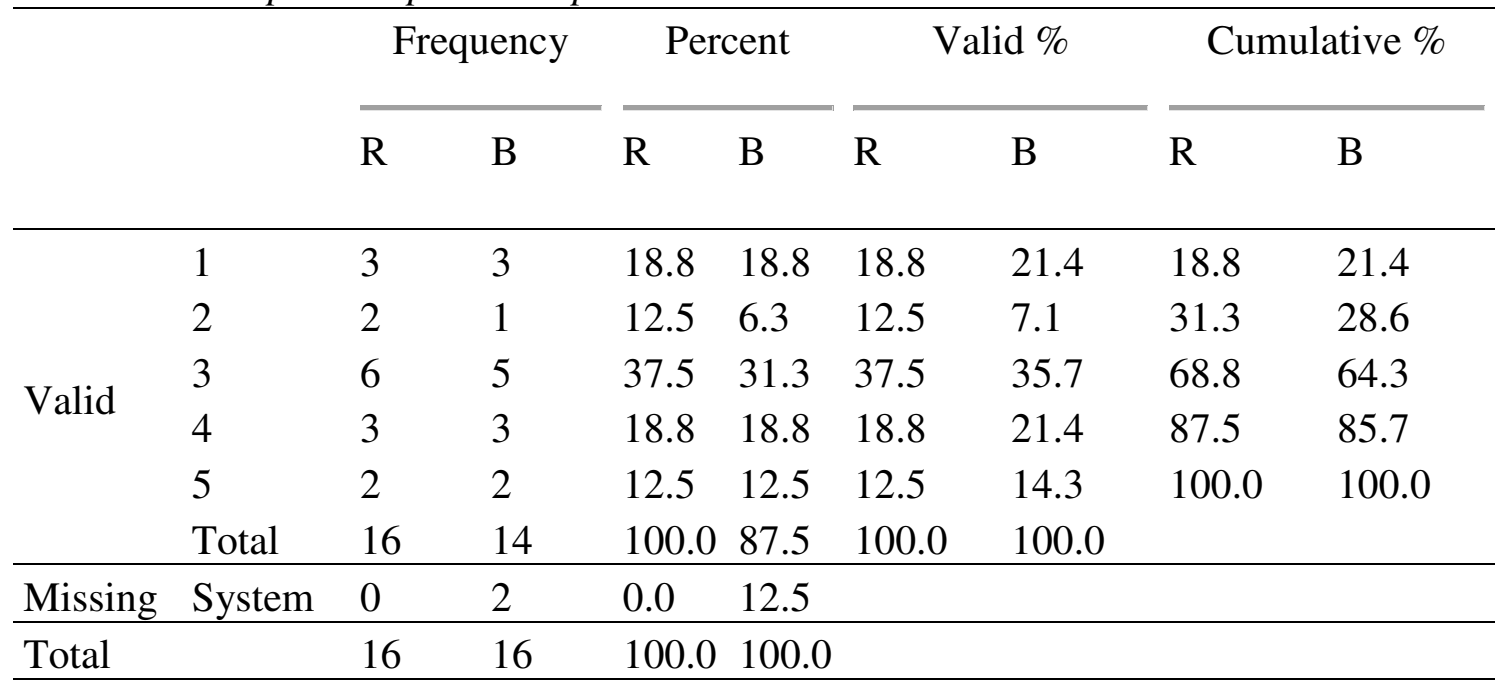

Note. $1=$ Strongly opposed $3=$ Somewhat interested in considering, but would want to do some research $5=$ This sounds very exciting and I would be very interested.

$\mathrm{R}=$ Respondent $\mathrm{B}=\mathrm{Board}$

\section{Variance by Position Held by Responder}

The final area for analysis involves answering the third research question of whether or not there was a statistically significant difference between the responses of school administrators and board presidents / chairmen. Using ANOVA testing, each of the items in this survey were tested for variance based on the position of the responder as a school administrator or board chairman. While differences by position did not rise to the level of statistical significance $(\mathrm{p}<.05)$ for most categories, there were a few noteworthy areas in which it did. The first two areas in which this variance became significant are closely related: scenarios four and five.

In scenario four, school leaders were asked about their interest in offering classes for adults from local churches such as training for Sunday School teachers using their existing faculty. While the mean response for both administrators and board members fell 
below the level of somewhat interested, school administrators were significantly more interested than board chairmen were. The mean response for administrators was 2.74 , which approaches the somewhat interested level. The mean response for board members on the other hand was only 2.00 , which suggests a much lower level of interest. Interestingly, administrators were also more likely to expect that their school boards would endorse such an approach with a mean expected school board response of 2.51 from administrators while board chairmen rated the chances their boards would be interested in this at a much lower level of 1.90 .

The next scenario asked a very similar question and thus received a similarly divided response. School leaders were asked about their interest in creating curriculum materials to sell to churches or other Christian schools. Administrators were slightly more interested in this than they were in offering classes with a mean response of 2.87 while board members remained far less interested with a mean response of 2.05 .

These findings answer the third research question by suggesting that board chairmen and Christian school administrators see most elements of social enterprise in a way that is statistically similar to each other and yet they differ when it comes to providing services to local churches. This would lend itself well to a follow up study used to determine the reasons why school board chairmen are less interested in this, and whether or not it is reflective of a difference in overall viewpoint as to the relationship between the Christian school and the local church. 


\section{Chapter 5: Discussion and Implications}

The purpose of this study was to determine the interest of school administrators and board presidents in exploring social enterprise based funding solutions. The overall results of the survey yielded a number of useful conclusions. The fact that there was a significant degree of separation between the results by category of social enterprise provides useful information for decision makers on not only the overall interest of Christian school leaders in pursuing social enterprise, but more specifically on the forms of social enterprise they are open to. The narrow focus of this study both in terms of subject matter and geography allows for the direct application of these conclusions within the population for the study, and should encourage future studies to determine the degree to which these results can be generalized.

\section{Interpretation and Application}

Analysis of the data gathered through this study will focus primarily on the three initial research questions around which the study was designed. The first research question for this study was the degree to which social enterprise was of interest to Christian School leaders at Association of Christian Schools International (ACSI) Christian schools in the Mid-America region. The results of this study show that interest in social enterprise is slightly below the "somewhat interested" level reflecting an overall sense of significant caution towards this approach to fund raising on the part of the 
surveyed Christian school leaders. Yet, just as important to analyzing the results of the first question is the degree to which responses varied between schools. While the overall trend suggests significant caution on the part of school leaders, the complete picture is still one of wide variability between schools.

Another major conclusion from this study in relation to the first research question is the difference between the overall current involvement of ACSI Christian schools in social enterprise and their level of interest in pursuing these funding options. Currently only a very small percentage of ACSI Christian schools in the Mid-America region participate in social enterprise based fund raising approaches. The notable exceptions were in the area of traditional fund raisers and appropriation of space to noncommercial organizations. While this overall current involvement is low, the survey results show that a number of school leaders have an interest in considering these approaches in the future. This is seen most clearly in the five subcategories in which both current involvement and interest were assessed. In these cases data for schools currently not participating in the respective form of social enterprise were able to be isolated to show that schools not currently participating have an interest in doing so. While mean scores appear to show this pattern extending to other subcategories, this cannot be assumed with complete confidence without further study.

The most significant results coming from this study are in reference to the second research question. This question focused on the degree to which schools were interested in specific forms of social enterprise. While the level of interest shown by school leaders in applying social enterprise was below "somewhat interested" when looked at as an 
overall mean score, there were some very critical trends in which particular activities captured the interest of these leaders and others were clearly not seen as viable options. These trends should inform future exploration of this topic and financial planning efforts of Christian school leaders.

The first theme occurring in the data was that school leaders were most inclined to pursue social enterprise opportunities that connected most directly with their target audience and were thus a closer fit with their current mission. This is seen specifically in the preference of school leaders for tutoring or child care for their existing families over offering these same services to families outside their school by nearly a full point on the five point Likert scale. This suggests that Christian school leaders are far less open to programs designed for an outside audience than they are to programs designed for their own students.

Schools also seemed more open to indirect promotion of products than direct promotion (Browder, 2007). When schools were asked about corporate sponsorships interest was fairly strong with a mean response of 3.46 on a five point scale. Yet, when asked about directly promoting products the mean dropped down by almost 1.5 points on a five point scale to 2.05 . This represents a strong message from the school leaders that they are far more interested in forms of social enterprise when the benefit to their students is clear and when the commercial message is more subtle or at least does not appear to amount to a direct endorsement by the school.

Similarly, schools showed a greater interest in promoting products through more traditional channels. When schools were asked about their current practices $64.4 \%$ of 
schools rated their involvement in traditional fund raisers in which students directly sell a product or service as moderate or greater. Only $13.6 \%$ of school leaders said that their school had no involvement with this traditional form of fund raising. Yet, when asked about a scenario in which the school would promote products, services, or retailers to their school families, the response was much lower with a mean response of 2.05 on a five point Likert scale in which a 3 is considered "somewhat interested" and 1 is "strongly object." Thus, schools are generally far more accepting of promoting products through traditional fund raisers than they are of promoting products directly to their school families either online or offline.

The response of schools as to their current involvement in traditional fund raising such as students selling candy is also significant in looking at the broader field of social enterprise in schools. It reflects a philosophical openness to using business based practices to raise money for schools. While the boundaries of where schools are willing to go with this may vary significantly from school to school, schools are demonstrating by their practices that they have at least some level of openness to this field and do not object on religious or moral grounds.

Data related to the third research question offers far less in the way of broad themes. In general, administrators and board members seemed to answers questions similarly enough that there were not any statistically significant differences in their views on most of the scenarios. Nor were there statistically significant differences in their representations of the degree to which their school currently participates in most of the fund raising practices about which they were asked. The notable exceptions were in the 
areas of developing curriculum for churches and other Christian schools as well as teacher training classes. In these areas administrators had a statistically significant greater interest in pursuing these opportunities in more detail. Answering the question of why this takes place is beyond the scope of this study and provides excellent material for a future study. However, it can reasonably be concluded that efforts to implement this form of social enterprise should most likely start with administrators first given their greater interest in this topic.

The results of this research provide a base for both further research and the potential application of social enterprise in the Christian school setting. First, the divide existing between the current practice of schools and the level of interest suggests that there is opportunity for one or more organizations to assist interested schools in pursuing social enterprise based funding approaches. The difference between the levels of involvement and the mean scores on questions assessing the interest level of school leaders demonstrates that while overall responses to social enterprise based approaches were less than enthusiastic, an interest on the part of administrators that goes beyond the level of current practice does exist for a number of schools. In light of this, any efforts to promote social enterprise among Christian schools should involve research into what schools are interested and possibly demographic or other factors that are statistical predictors of a school's level of interest in social enterprise.

The preference of school administrators for programs that enhance their offerings to their existing population also offers many practical opportunities for research informed practice. There appears to be an interest in making Christian schools into organizations 
that meet a broader spectrum of the needs for their school families in a way that allows them to also earn additional income. Such programs may range from child care to tutoring services to any host of other opportunities where families may be inclined to otherwise spend money outside of the school environment. Social enterprise based programs that serve their existing population offer schools a rich base in that they are able to be competitive by nearly eliminating the significant advertising expense that other companies would have in providing products or services to this same group.

Similarly, social enterprise based solutions seem most likely to be successful when the benefit to the students is the primary focus and the commercial benefit for the company is more subtle. Schools were hesitant when it came to directly promoting products for companies; however, there was a very high level of interest in corporate sponsorships. Thus, companies interested in engaging in social enterprise based funding solutions with schools should consider that ACSI Christian schools in the Mid-America region are likely to be far more interested in solutions that involve a corporate sponsorship than they are in directly promoting their product. They would be well advised to design their school based promotions around this.

In addition, organizations seeking to promote social enterprise among Christian schools should generally avoid straying too far from more traditional approaches to fund raising when it comes to the direct promotion of products and services offered by outside companies. The data suggests that while there may be seemingly little difference between a school directly promoting a product through various communication channels and a school having their students sell a product to in some way financially benefit the school, 
school leaders are far more open to the latter scenario. While the reasons for this extend beyond the scope of this study, a general attitude of caution should be applied by those seeking to design a program in which a Christian school within the population of this study directly promotes a product, service, or retailer.

Finally, those promoting social enterprise among Christian schools should avoid any type of arrangement in which an outside organization rents space from a school during school hours. School leaders showed a clear disinterest in and even an objection to having outside groups renting out space in their buildings during the school day. The reasons for this could be varied with some schools putting notes on their surveys indicating that for one reason or another this is simply not a logistical option for them. Others may be worried about student safety with the images of school shooting victims etched into the minds of millions of Americans after two decades of numerous school tragedies. Whatever the reasons may be, schools were not generally interested in this and it should thus be avoided.

\section{Biblical Integration}

Approaching the concept of social enterprise in the Christian school environment from a biblical perspective requires an examination of four biblical themes. These themes form the basis for a balanced approach to social enterprise based funding in which moderation becomes the focus. The first of these themes is loving God rather than money. The second theme is that money is most adequately understood when it is seen as an amoral tool that should be used to provide for daily needs and in the promotion of God's kingdom agenda. The third theme is that of love and the pursuit of the best interest 
of others, and the final theme is that of pursuing mercy and justice for the disadvantaged. These four themes taken in combination help to create a biblical vision for the application of social enterprise to the Christian school environment while also presenting clear warnings as to what schools should avoid.

The first theme of loving God rather than money (Matthew 6:24) presents a warning that may temper the enthusiasm of some Christian school leaders toward the concept of social enterprise. The Bible clearly shows that money can become a temptation and an idol (1 Timothy 6:10). Yet, these passages are also often misinterpreted to say that money in itself is evil. A biblical view of money portrays it as not inherently evil but rather a potential idol which must be guarded against. While this tendency to idolize money must be guarded against, it does not make money itself evil.

Scripture portrays money as a tool (Luke 16:9). It in itself is amoral. It can and should be used for the care of one's family (1 Timothy 5:8). It should be used to pay the government what they are due (Mark 12:17). It is well used when it is spent on the care of others (Luke 10:25-37). Finally it is to be used in the building of God's kingdom. While it is true that money can be misused as an idol, it is just as true that it is a resource that is to be effectively stewarded and used as a tool for building God's kingdom. This should be kept in mind when addressing the issue of social enterprise in a Christian school setting.

Furthermore, scripture gives guidelines relative to the way in which those who would follow Christ with their lives are to treat others. These guidelines provide one piece of the Christian's overall framework for the wise stewardship of money. 
Throughout the New Testament believers are told to live lives characterized by love (1 John 4:7-10). This love involves looking to the needs of others rather than one's own needs or desires (1 Cor. 13). As all other elements of the Christian's life, money is to be managed and stewarded according to this principle of love. Pursuing it for the sake of meeting the needs of others is a noble task.

In a similar way, Christians are commanded to show love specifically to the widows and the orphans, those ignored by or cast out from main stream society (James $1: 27)$. This becomes a specific manifestation of the overall spirit of love that is to come naturally to believers as they imitate their master. The believer should seek to minister to the needy as a way of showing the love that characterizes Christ Jesus. This should be a guiding principle in the way that the believer's money is spent and in the way in which the believer pursues financial resources.

These four biblical themes create a framework for a correct theology of money which should guide a believer's attempt at understanding social enterprise at it applies to the Christian school setting. Social enterprise is a means by which funds can be obtained for the purpose of providing for the needs of a school, showing love to others, and looking after the needs of those who could benefit greatly from a Christian school education, but may not be able to afford the price tag. It can be used as a tool to minister to the widow and the orphan, the families that have become outcasts. What a testimony it would be for the love with which believers have been loved if Christian schools were able to open their doors to provide a quality Christian education to every family interested in it and willing to make moderate sacrifices. 
At the same time, in examining social enterprise as a potential source of funds for Christian schools, the warning found in the book of 1 Timothy regarding the pursuit of money should not be dismissed without careful thought. Money can be a great temptation. Throughout scripture and throughout history Satan has used it to tempt many believers into behaving in ways that they might not have thought themselves capable of. Social enterprise is a tool. If used properly it can be a source of great benefit and a way to show the love of Christ. Yet, if handled poorly, the love of money can overcome the desire to serve God and what started as a noble and God honoring task can become the story of the fall of an individual or an organization collectively into significant sin. Thus, social enterprise based fund raising must be handled with care. There is biblical support for its use as there is biblical support for any legitimate pursuit of money for the sake of building God's kingdom and showing love to others. At the same time it must be handled with care so as not to take an honorable pursuit and turn it into idolatry.

\section{Relation of the Results to Literature}

Just as this research finds its foundation in the existing literature, it also contributes to that literature. This study is a pioneering study in that it is the first study of its kind to explore social enterprise in an ACSI Christian school setting. Yet, connections can still be drawn between the findings and the broader literature on social enterprise and commercialism in schools.

The results of this study show a clear pattern in which schools are more likely to pursue social enterprise based fund raising approaches if they contribute primarily to the school's target audience and its mission. While many of these Christian school leaders 
are not likely to be familiar with the literature on the field of social enterprise, their choices are consistent with its findings. When not handled carefully social enterprise has a tendency to cause a drift from the organization's primary mission (Yunus, 2007; Page \& Katz, 2010; Hudson 2009). Leaning more heavily toward forms of social enterprise that build on the school's mission such as additional child care and tutoring help for their existing students helps to avoid this. In this way the approach taken by these school leaders fits with literature on social enterprise that portrays it as a relatively new and unproven concept that holds great promise, but should be approached with care (Raymond, 2010).

Further connections can be established between the existing literature and the results of this study by examining connections between the use of commercialism in public school funding and the practices of Christian schools shown in this study. In Bobby Browder's study of the views of school superintendents in the state of Virginia toward commercial advertising, numerous forms of commercial activity in public schools were seen as okay by the superintendents surveyed, but direct promotion of products by teachers in their classroom was viewed as unacceptable (Browder, 2007). Similarly the current study shows that Christian school administrators draw a significant line between direct and indirect forms of product promotion. School leaders showed a significant interest in corporate sponsorships, but were far more hesitant when it came to direct promotion of products, services, or franchises by the school.

In a similar study Lunden (2007) examined the involvement of public schools in the state of New York in commercial activity. Of greatest interest in light of the current 
study is the way in which Lunden's work breaks down the commercial involvement of schools in New York by subtypes. This allows for comparison between this study's findings relative to ACSI Christian schools in the Mid-American region of the country and the involvement of public schools in the state of New York. Overall involvement of ACSI Christian schools in nearly every element of social enterprise exceeded that of the public schools in New York. Lunden's study showed 23\% of schools engaging in exclusive agreements with outside companies while $31.7 \%$ of ACSI Christian school leaders surveyed reported that their schools were already involved in this. In a more drastic contrast, only $7 \%$ of New York public schools reported engaging in appropriation of space while 55\% of ACSI Christian schools reported engaging in appropriation of space with $33.3 \%$ of these engaging in appropriation of space for commercial purposes. In the area of electronic marketing, only one percent of New York State's public schools were involved whereas $11.7 \%$ of Christian school leaders surveyed reported involvement. Traditional fund raising was the most common commercial practice in Lunden's research and also topped the charts in the current study with 55\% of New York's public schools engaged in this practice and $86.4 \%$ of Christian school leaders surveyed reporting that their schools were involved. The one exception to this pattern of greater involvement for the Christian schools is in the area of commercial incentive programs. In this area $52 \%$ of New York public schools were involved while only $40.4 \%$ of Christian school leaders surveyed reported their school was involved. The final category does not allow for a direct comparison between the two organizations but does allow for some side by side comparison. In Lunden's study 15\% of New York public schools were using sponsored educational materials and 6\% were utilizing sponsorships of programs and activities. 
While this question was not posed to Christian school leaders in the current study, school leaders were asked about their interest in corporate sponsorships. The response was overwhelmingly positive with $84.7 \%$ expressing an interest.

The overall take away from analyzing the Lunden study and the current study of ACSI Christian schools is that in many ways the attitudes of Christian school administrators parallel those of public school administrators in terms of what forms of social enterprise are of greatest interest. Where they begin to diverge is in the degree of implementation of social enterprise. Social enterprise based approaches are already far more common in ACSI Christian schools in the Mid-America region than they are in public schools in the state of New York.

The conclusion that when convinced to engage in the promotion of a product, Christian schools seem to gravitate more strongly to traditional channels for promoting these products is consistent with the overall portrayal of Christian schools in the literature. Christian schools are on the whole conservative organizations (Laats, 2010; Swezey, 2006). This study further extends this understanding of Christian schools as largely conservative institutions by suggesting of them a tendency to be fiscally conservative in addition to being morally and socially conservative. As fiscally conservative organizations, Christian schools and their leadership are open to traditional forms of fund raising in which students directly promote products and services, but are far more hesitant to directly promote a product as a school.

In addition, the literature reveals limited attempts at applying social enterprise in both the postsecondary education setting (Violino, 2007) and the catholic school setting 
(Couture, 2007; Kearney, 2008). This study expands upon the existing research base both in its nature and in the population studied. Each of the previously noted studies have been case studies in which specific examples of social enterprise have been studied. This study provides quantitative data to examine how open ACSI school leaders in the Mid-America region are to extending these findings beyond these limited cases.

Finally, this study finds its foundation in limited literature already in existence suggesting the application of social enterprise based strategies to the independent school environment (Affordability and demand, 2009). This study expands on the literature first in that it is the first to connect the term social enterprise to this approach to school funding. Secondly, it expands upon the existing literature in that it goes beyond conjecture to determine the actual level of interest in applying these strategies.

Thus, this study finds its foundation in the literature from both the nonprofit world as it relates to social enterprise and the education world as it relates to school funding. This study is generally consistent with the existing literature in each field. At the same time, as it draws on both sets of literature, this study expands the existing literature by providing valuable data as to the interest of ACSI Christian school leaders in the MidAmerica region in applying social enterprise based fund raising strategies.

\section{Strengths of the Study}

As previously noted, this was a pioneering study. As such its greatest strengths lie in the foundation it provides for studying the application of social enterprise to the Christian school setting. Prior to this study, social enterprise existed as a completely separate body of literature from the literature on school finance and commercialism in 
schools. This study links these two fields for the first time. This connection allows for literature from the field of social enterprise to begin to influence the literature and understanding of educational finance and in particular commercialism in schools.

Just as important as the bridge this study creates between two previously separate bodies of literature is the initial data set this study provides for the application of social enterprise to the Christian school setting. Since the literature in these fields had not been previously linked, no studies had been done investigating whether Christian schools were even open to applying the literature from this field. Without this important information it would become difficult to determine whether further research would even be justifiable from a pragmatic perspective.

In providing a basic data set related to the level of support for social enterprise among Christian school leaders in the Mid-America region, this study demonstrates an overall strength of methodology. The study was a non-experimental survey research project. Every member of the population group was sampled so as to avoid any risk of selection error. The response rate for the survey was sufficient given the lack of generalization needed. ANOVA testing provided further confirmation of the absence of bias based on the way in which the survey was administered.

\section{Limitations of the Study}

While every effort was made to insure the validity of this data, the greatest remaining limitation in this study is the response rate. While the response rate is sufficient, hovering around $60 \%$, a higher response rate would have better guaranteed that 
the data can be generalized to portions of the population not responding to the survey. This would have given the researcher a greater level of confidence in the results.

A second major limitation of this study was in the population studied. By limiting the surveys to only the Mid-America region and only ACSI schools, the ability to generalize this study on a broad scale is severely limited. This data cannot accurately be generalized to Christian schools in other areas of the country, nor can it be generalized to smaller Christian schools. This lack of ability to generalize this data makes it less likely that the data will be able to be broadly used without follow-up studies.

Furthermore, this study was limited by the length of the survey. The researcher intentionally kept the survey short to encourage a greater response rate. However, in doing so, each fund raising approach had to be operationalized by only one scenario. Additional questions operationalizing each approach in a different way would have provided a greater confidence in the degree to which each scenario effectively represented the approach to social enterprise based school fund raising that it was attempting to represent.

Finally, this study was limited by the scope of the scenarios included in the survey. While each scenario was intentionally chosen to capture as large a general category of social enterprise based fund raising as possible, it is still likely that there are potential approaches that were not polled. This limits the ability of this study to represent the overall view of school leaders as it relates to the application of social enterprise as a whole to the Christian school context. 


\section{Suggestions for Further Research}

As a pioneering study, this research was intended first and foremost to start a conversation on the application of the literature on social enterprise to the funding challenges faced by Christian schools. As such it was designed to be the first of many studies to create an accurate literature base for schools to use in their decision making process. Further studies needed fall into three primary categories. First, further research is needed to investigate the views of ACSI Christian school leaders as they relate to other elements of social enterprise as well as to confirm the findings related to the current subsets. Secondly, further research is needed to determine the degree to which these findings can be generalized to schools in other geographic areas and of other types. Finally, further research is needed to determine what elements of a school's overall demographic profile and other characteristics correlate most closely with their acceptance of these approaches and success in implementing them.

Further research needed on the views of ACSI Christian school administrators includes a broader subset of potential applications of social enterprise to the Christian school context. This study only provided participants with nine scenarios. While these nine scenarios were designed to be broad enough to cover many potential applications of social enterprise, they cannot possibly cover all of the potential applications. In addition, the limited number of scenarios given means that each subset of the application of social enterprise to the Christian school context was only able to be represented by one scenario. Further research should confirm the findings of this study by operationalizing 
the subsets of the overall field in different ways to insure that consistent responses are provided.

Beyond studies that create a clearer picture of the views of ACSI Christian school leaders in the Mid-America region, this study would be greatly enhanced by studies determining the degree to which the results obtained here carry over to schools in other geographic areas and across other school types. This study was very narrow in both its geographic focus and in the types of schools studied. Future research will be needed to determine if these findings apply to schools in other areas of the country as well as to other schools. For example, it would be helpful to know if leaders of smaller Christian schools would provide responses similar to those provided here. Similarly, Christian schools not affiliated with ACSI and other forms of private schools can and should be studied to determine the degree to which the results of this study do or do not generalize to these populations.

Finally, while this study provides information on overall trends, further research is needed to determine what factors of a school best correlate with schools whose leaders are interested in pursuing various forms of social enterprise based funding. While general trends are helpful, having these correlations would make it much easier for organizations seeking to encourage social enterprise to effectively target the schools most likely to support this approach. The current study showed a wide variation between schools for many of the scenarios studied, so having data to suggest what schools would be most likely to be enthusiastic about approach social enterprise based fund raising would have a great deal of practical significance. 
SOCIAL ENTERPRISE AND CHRISTIAN SCHOOL FINANCE

\section{References}

ACSI annual school survey 2008-09 (Rep.). (2009). Retrieved July 21, 2009, from Association of Christian Schools International website: http://www.acsi.org/LinkClick.aspx?fileticket=4UK8XmL2Y08\%3d\&tabid=568

Association of Christian Schools International. (n.d.). ACSI FAQ. Retrieved October 20, 2012, from http://www.acsiglobal.org/home-2/faq

Aud, S., Hussar, W., Kena, G., Bianco, K., Frohlich, L., Kemp, J., \& Tahan, K. (n.d.). The condition of education 2011 (Rep.). National Center for Education Statistics. Retrieved from http://0www.eric.ed.gov.library.cedarville.edu/contentdelivery/servlet/ERICServlet?accn o=ED520001 (ERIC Document Reproduction Service No. ED520001)

Bassett, P. (2010). High anxiety, the sequel. NAMTA Journal, 35(1), 138-143. Retrieved from Education Research Complete.

Beadie, N. (2008). Tuition funding for common schools. Social Science History, 32(1), 107-133. Retrieved from Academic Search Complete.

Bielefeld, W. (2009). Issues in social enterprise and social entrepreneurship. Journal of Public Affairs Education, 15(1), 69-86. Retrieved from Education Research Complete. 
SOCIAL ENTERPRISE AND CHRISTIAN SCHOOL FINANCE

Blokhuis, J. C. (2008). Channel One: When private interests and the public interest collide. American Educational Research Journal, 45(2), 343-363. Retrieved from Electronic Journal Center.

Boudah, D. J. (2011). Conducting educational research: Guide to completing a major project. Thousand Oaks, CA: SAGE Publications.

Brent, B. O., \& Lunden, S. (2009). Much ado about very little: The benefits and costs of school-based commercial activities. Leadership and Policy in Schools, 8(3), 307336. Retrieved from Education Research Complete.

Browder, B. R. (2007). Commercialism in public schools: A study of the perceptions of superintendents accepting corporate advertising in Virginia (Unpublished doctoral dissertation). Virginia Polytechnic Institute and State University.

Casselman, B. (2007, June 1). Why 'social enterprise' rarely works. Wall Street JournalEastern Edition, p. W3.

Check, J. W., \& Schutt, R. K. (2011). Research methods in education. Thousand Oaks, CA: Sage Publications.

Choudhurt, Y., Hussain, I., Parsons, S., Rahman, A., Eldridge, S., \& Underwood, M. (2012). Methodological challenges and approaches to improving response rates in population surveys in areas of extreme deprivation. Primary Health Care Research \& Development, 13(3), 211-218. Retrieved from Academic Search Premier. 
Colson, H. A. (2009). Philanthropy at independent schools. Washington, D.C.: National Association of Independent Schools.

Converse, P. D., Wolfe, E. W., Huang, X., \& Oswald, F. L. (2008). Response rates for mixed-mode surveys using mail and e-mail/web. American Journal of Evaluation, 29(1), 99-107. Retrieved from ERIC.

Cortina, K. S., \& Frey, K. (2009). Privatschulen in den USA: Geschichte und aktuelle kontroversen [Private schools in the U.S.: History and current controversies]. Zeitschrift Für Pädagogik, 5, 701-715. Retrieved from Education Research Complete.

Coulson, A. J. (2009). Comparing public, private, and market schools: The international evidence. Journal of School Choice, 3(1), 31-54. Retrieved from Education Research Complete.

Coulson, A. J. (2011). Do vouchers and tax credits increase private school regulation? A statistical analysis. Journal of School Choice, 5(2), 224-251. Retrieved from Education Research Complete.

Couture, B. G. (2007). A Freirean critique of the Cristo Rey Network's transformation: Assimilation or liberation? (Doctoral dissertation, Loyola University). ProQuest. Retrieved from Dissertations \& Theses: A\&I. 
Cowie, L., Myfanwy, M., \& Gulliford, M. (2011). Handwritten 'post-it' notes, questionnaire formats and response to a postal questionnaire survey. International Journal of Epidemiology, 40(1), 254-255. Retrieved from Academic Search Complete.

Crampton, F. E. (2010). The economics and financing of urban schools: Toward a productive, solution-oriented discourse. Educational Considerations, 38(1), 3339. Retrieved from Education Full Text.

Culbertson, B. K. (2008). Supplementing annual school district budgets: Partnerships, fundraisers, foundations, and local support venues (Unpublished doctoral dissertation). University of North Texas.

Davison, D. R., Jr., \& Davison, J. (Eds.). (2009). Affordability and demand. Washington DC: National Association of Independent Schools.

The Dayton Agenda. (2009). Journal of Research on Christian Education, 18, 11-19. doi: $10.1080 / 10656210902751784$

Definitions. (2007). ASHE Higher Education Report, 33(3), 7-16. doi: 10.1002/aehe.3303

Donlevy, J. (2010). Teachers, technology and training: Continuing financial challenges as districts face budget year 2010-2011. International Journal of Instructional Media, 37(2), 117-118. Retrieved from Academic Search Complete. 
SOCIAL ENTERPRISE AND CHRISTIAN SCHOOL FINANCE

Duncombe, W., Lukemeyer, A., \& Yinger, J. (2008). The No Child Left Behind Act: Have federal funds been left behind? Public Finance Review, 36(4), 381-407. Retrieved from Business Source Complete.

Edwards, P., Roberts, I., Clarke, M., DiGuiseppi, C., Wentz, R., Kwan, I., ... Pratap, S. (2009). Methods to increase response to postal and electronic questionnaires. Cochrane Database of Systematic Reviews. Retrieved from CINAHL Plus with Full Text.

Figlio, D., \& Hart, C. M. (2011). Does competition improve public schools? New evidence from the Florida tax-credit scholarship program. Education Next, 11(1), 74-80. Retrieved from Education Full Text (H.W. Wilson).

Garner, R. (2005). Post-It ${ }^{\circledR}$ note persuasion: A sticky influence. Journal of Consumer Psychology, 15(3), 230-237. Retrieved from Academic Search Complete.

Garnet, N. S. (2010). Affordable private education and the middle class city. University of Chicago Law Review, 77(1), 201-222. Retrieved from Academic Search Complete.

Go, S., \& Lindert, P. (2010). The uneven rise of american public schools to 1850 . The Journal of Economic History, 70(1), 1-26. Retrieved from Electronic Journal Center.

Hartas, D. (2010). Educational research and inquiry: Qualitative and quantitative approaches. London: Continuum. 
SOCIAL ENTERPRISE AND CHRISTIAN SCHOOL FINANCE

Hillen, T. (2008). Christian fundamentals of business functions. Christian School Education, 11, 10-11.

Howell, W. G., West, M. R., \& Peterson, P. E. (2011). The public weighs in on school reform. Education Next, 11(4). Retrieved from Education Full Text (HW Wilson).

Huber, J. B. (2007). The accessibility of american catholic secondary schools to the various socioeconomic classes of catholic families. Catholic Education: A Journal of Inquiry \& Practice, 10(3), 271-287. Retrieved from Education Full Text (H.W. Wilson).

Hudson, R. (2009). Life on the edge: Navigating the competitive tensions between the 'social' and the 'economic' in the social economy and in its relations to the mainstream. Journal of Economic Geography, 9(4), 493-510. Retrieved from Electronic Journal Center.

Huerta, L. A., \& D'Entremont, C. (2007). Education tax credits in a post -Zelman eraLegal, political, and policy alternatives to vouchers? Education Policy, 12(1), 73109. Retrieved from Academic Search Complete.

James, J. T. (2007). Changes in funding and governance of catholic elementary education in the United States. British Journal of Religious Education, 29(3), 287-301. Retrieved from Education Research Complete.

Jeynes, S. (2007). The tuition book: Theory, implementation and financial aid. Wilmington, DE: Independent School Management. 
SOCIAL ENTERPRISE AND CHRISTIAN SCHOOL FINANCE

Jimenez-Castellanos, O. (2010). Relationship between educational resources and school achievement: A mixed method intra-district analysis. Urban Review, 42(4), 351371. Retrieved from Education Full Text (H.W. Wilson).

Johnson, B., \& Christensen, L. B. (2008). Educational research: Quantitative, qualitative, and mixed approaches. Los Angeles, CA: Sage Publications.

Katz, R. A., \& Page, A. (2010). The role of social enterprise. Vermont Law Review, 35(1), 59-103. Retrieved from Academic Search Complete.

Kearney, G. R. (2008). More than a dream: The Cristo Rey story : How one school's vision is changing the world. Chicago, IL: Loyola Press.

Kelley, T. (2009). Law and choice of entity on the social enterprise frontier. Tulane Law Review, 84(2), 337-377. Retrieved from Academic Search Complete.

Kerlin, J. A. (2010). A comparative analysis of the global emergence of social enterprise. Voluntas: International Journal of Voluntary \& Nonprofit Organizations, 21(2), 162-179. Retrieved from Academic Search Complete.

Kirkman, D. M. (2012). Social enterprise: An multi-level framework of the innovation adoption process. Innovation: Management, Policy, \& Practice, 14(1), 143-155. Retrieved from Business Source Complete. 
SOCIAL ENTERPRISE AND CHRISTIAN SCHOOL FINANCE

Kroth, P. J., McPherson, L., Leverence, R., Pace, W., Daniels, E., Rhyne, R., \& Williams, R. (2009). Combining web-based and mail surveys improves response rates: A PBRN study from PRIME Net. Annals of Family Medicine, 7(3), 245-248. Retrieved from Academic Search Premier.

Kruska, R. (2008). Financial models in catholic education (Unpublished doctoral dissertation). Loyola Marymount University. Retrieved from Proquest Dissertations \& Thesis A\&I.

Kubik, M. Y., Lytle, L. A., Farbakhsh, K., Moe, S., \& Samuelson, A. (2009). Food used in middle and high school fundraising: Does policy support healthful practice? Results from a survey of Minnesota school principals. Journal of the American Dietetic Association, 109(7), 1215-1219. Retrieved from Academic Search Complete.

Laats, A. (2010). Forging a fundamentalist 'one best system': Struggles over curriculum and educational philosophy for Christian day schools, 1970-1989. History of Education Quarterly, 50(1), 55-83. Retrieved from Education Research Complete.

Ladson-Billings, G. (2007). Pushing past the achievement gap: An essay on the language of deficit. Journal of Negro Education, 76(3), 316-323. Retrieved from Education Full Text. 
Lang, R., \& Carrott Minnigh, E. (2010). The L3C history, basic construct, and legal framework. Vermont Law Review, 35(1), 15-30. Retrieved from Academic Search Complete.

Lavelle, K., Todd, C., \& Campbell, M. (2008). Do postage stamps versus prepaid envelopes increase responses to patient mail surveys? A randomised controlled trial. BMC Health Services Research, 8, 1-5. Retrieved from Academic Search Complete.

Loeb, S., Valant, J., \& Kasman, M. (2011). Increasing choice in the market for schools: Recent reforms and their effects on students achievement. National Tax Journal, 64(1), 141-164. Retrieved from Business Source Complete.

Looney, S. (2009). Trends in demand and affordability. In D. R. Davison Jr. \& J. Davison (Eds.), Affordability and demand (pp. 17-24). Washington DC: National Association of Independent Schools.

Lunden, S. J. (2007). Corporate america inside the public school system: An analysis of commercial activities within New York state public schools (Unpublished doctoral dissertation). University of Rochester.

Making God known, loved, and served: The future of Catholic primary and secondary schools in the United States. (2008). Catholic Education: A Journal of Inquiry \& Practice, 11(3), 276-312. Retrieved from Education Full Text (H.W. Wilson). 
SOCIAL ENTERPRISE AND CHRISTIAN SCHOOL FINANCE

Massetti, B. L. (2008). The social entrepreneurship matrix as a "tipping point" for economic change. Emergence: Complexity \& Organization, 10(3), 1-8. Retrieved from Business Source Complete.

McKinley, S. K., \& Phillis, W. L. (2008). Collaboration in search of a school funding remedy post DeRolph. Journal of Education Finance, 33(3), 311-330. Retrieved from Education Full Text.

Meadows, M., \& Pike, M. (2010). Performance management for social enterprises. Systemic Practice \& Action Research, 23(2), 127-141. Retrieved from Business Source Complete.

Merrifield, J. (2008). The twelve policy approaches to increased school choice. Journal of School Choice, 2(1), 4-19. Retrieved from Education Research Complete.

Metz, S. (2010). New tools for learning. Science Teacher, 77(7), 6-6. Retrieved from Education Research Complete.

Meyer, P. (2007). Can Catholic schools be saved?: Lacking nuns and often students, a shrinking system looks for answers. Education Next, 7(2), 12-20. Retrieved from Education Full Text (H.W. Wilson).

Mitchell, M. J. (2009). The affordability conundrum: Tuition, income, and financial aid realities and strategies. In D. R. Davison \& J. Davison (Eds.), Affordability and demand (pp. 109-138). Washington, DC: National Association of Independent Schools. 
SOCIAL ENTERPRISE AND CHRISTIAN SCHOOL FINANCE

Moizer, J., \& Tracey, P. (2010). Strategy making in social enterprise: The role of resource allocation and its effects on organizational sustainability. Systems Research \& Behavioral Science, 27(3), 252-266. Retrieved from Business Source Complete.

Nulty, D. D. (2008). The adequacy of response rates to online and paper surveys: What can be done? Assessment \& Evaluation in Higher Education, 33(3), 301-314. Retrieved from Academic Search Complete.

O'Keefe, J. M., \& Scheopner, A. J. (2009). Bridging the gap: Urban Catholic schools addressing educational achievement and opportunity gaps in the United States. International Studies in Catholic Education, 1(1), 15-29. Retrieved from Education Research Complete.

Page, A., \& Katz, R. (2010). Freezing out Ben \& Jerry: Corporate law and the sale of a social enterprise icon. Vermont Law Review, 35(1), 211-250. Retrieved from Academic Search Complete.

Popielarski, J., \& Cotugna, N. (2010). Fighting hunger through innovation: Evaluation of a food bank's social enterprise venture. Journal of Hunger \& Environmental Nutrition, 5(1), 56-69. Retrieved from Environment Complete.

Raymond, S. (2010). Changing strategies for philanthropic giving: Implications for financial planners. Journal of Financial Planning, 23(11), 44-49. Retrieved from Business Source Complete. 
SOCIAL ENTERPRISE AND CHRISTIAN SCHOOL FINANCE

Reiser, D. B. (2010). Blended enterprise and the dual mission dilemma. Vermont Law Review, 35(1), 105-116. Retrieved from Academic Search Complete.

Rookey, B. D., Le, L., Littlejohn, M., \& Dillman, D. A. (2012). Understanding the resilience of mail-back survey methods: An analysis of 20years of change in response rates to national park surveys. Social Science Research, 41(6), 1404-1414. Retrieved from Academic Search Complete.

Ryan, P. W. (2008). Social enterprise and the measurement of social value: Methodological issues with the calculation and application of the social return on investment. Education, Knowledge \& Economy, 2(3), 223-237. Retrieved from Education Research Complete.

Sakellariou, C., \& Patrinos, H. A. (2009). The equity impact of public finance of private education in cote' d ivoire. International Journal of Educational Development, 29(4), 350-356. Retrieved from ERIC.

Salmon, R. G. (2010). The evolution of Virginia public school finance: From the beginnings to today's difficulties. Journal of Education Finance, 36(2), 143-161. Retrieved from Education Full Text.

Schmidt, E. (2010). Vermont's social hybrid pioneers: Early observations and questions to ponder. Vermont Law Review, 35(1), 163-210. Retrieved from Academic Search Complete. 
SOCIAL ENTERPRISE AND CHRISTIAN SCHOOL FINANCE

Sedivy, R. R. (2009). Cost containment and revenue growth strategies. In D. R. Davison Jr. \& J. Davison (Eds.), Affordability and Demand (pp. 73-95). Washington DC: NAIS.

Shalqvist, S., Yena, S., Bull, F., Adams, E., Preston, J., \& Ogilvie, D. (2011). Effect of questionnaire length, personalisation and reminder type on response rate to a complex postal survey: Randomised controlled trial. BMC Medical Research Methodology, 11(1), 62-69. Retrieved from Academic Search Premier.

Slater, C. L. (2011). California on the verge of a fourth wave of school finance reform. AASA Journal of Scholarship \& Practice, 8(2), 51-60. Retrieved from ERIC.

Smith, B. R., Cronley, M. L., \& Barr, T. F. (2012). Funding implications of social enterprise: The role of mission consistency, entrepreneurial competence, and attitude toward social enterprise on donor behavior. Journal of Public Policy \& Marketing, 31(1), 142-157. Retrieved from Business Source Complete.

Smith, B. R., Knapp, J., Barr, T. F., Stevens, C. E., \& Cannatelli, B. L. (2010). Social enterprises and the timing of conception: Organizational identity tension, management, and marketing. Journal of Nonprofit \& Public Sector Marketing, 22(2), 108-134. Retrieved from Business Source Complete.

Snyder, T. (1993). Digest of Education Statistics, 1993 (Publication No. 93292). Retrieved from http://nces.ed.gov/pubsearch/pubsinfo.asp?pubid=93292 
Snyder, T. D., \& Dillow, S. A. (2011). Digest of Education Statistics, 2011 (Publication No. 201-2001). Retrieved from http://nces.ed.gov/pubsearch/pubsinfo.asp?pubid=2012001

Socias, M., Chambers, J., Esra, P., \& Shambaugh, L. (2007). The distribution of teaching and learning resources in California's middle and high schools (Issues \& Answers, Rep. No. REL 2007-No. 023). Regional Educational Laboratory West. Retrieved from ERIC.

Springer, K. (2009). Educational research: A contextual approach. Hoboken, NJ: Wiley.

Strickland, S. (2009). The Kalamzoo promise: A study of philanthropy's increasing role in the economy and education. International Journal of Educational Advancement, 9(1), 16-34. Retrieved from Education Research Complete.

Sutton, L. C., \& King, R. A. (2011). School vouchers in a climate of political change. Journal of Education Finance, 36(3), 244-267. Retrieved from Education Full Text (HW Wilson).

Swezey, J. A. (2006). The founding and formation of the Association of Christian Schools International (Unpublished doctoral dissertation). George Fox University.

Tang, A. Y. (2011). Broken systems, broken duties: A new theory for school finance litigation. Marquette Law Review, 94(4), 1195-1239. Retrieved from Academic Search Complete. 
SOCIAL ENTERPRISE AND CHRISTIAN SCHOOL FINANCE

Teasdale, S. (2012). What's in a name?: Making sense of social enterprise discourse. Electronic Journal Center, 27(2), 99-119. Retrieved from Electronic Journal Center.

Tolbert, S. H., Moore, G. D., \& Wood, C. P. (2010). Not-for-profit organizations and forprofit businesses: Perceptions and reality. Journal of Business \& Economics Research, 8(5), 141-153. Retrieved from Business Source Complete.

Trebbe, S. E. (2009). Cain v. Horne: School choice for whom. Arizona Law Review, 51(3), 817-828. Retrieved from Academic Search Complete.

Trexler, J. (2008). Social entrepreneurship as an algorithm: Is social enterprise sustainable? Emergence: Complexity \& Organization, 10(3), 65-85. Retrieved from Business Source Complete.

Trivedi, C., \& Stokols, D. (2011). Social enterprises and corporate enterprises: Fundamental differences and defining features. The Journal of Entrepreneurship, 20(1), 1-32. Retrieved from Electronic Journal Center.

Umpstead, R. R. (2008). The No Child Left Behind Act: Is it an unfunded mandate or a promotion of federal educational ideals? Journal of Law \& Education, 37(2), 193229. Retrieved from Education Research Complete. 
SOCIAL ENTERPRISE AND CHRISTIAN SCHOOL FINANCE

U.S. Department of Education. (2008, September). Preserving a Critical National Asset: America's Disadvantaged Students and the Crisis in Faith-based Urban Schools. Retrieved from http://www2.ed.gov/admins/comm/choice/faithbased/report.pdf

Verstegen, D. A. (2011). Public education finance systems in the United States and funding policies for populations with special educational needs. Education Policy Analysis Archives, 19(21). Retrieved from ERIC.

Violino, B. (2007). Intellectual capital. Community College Journal, 77(6), 24-27. Retrieved from Education Research Complete.

Vogt, W. P., Gardner, D. C., \& Haeffele, L. M. (2012). When to use what research design. New York, NY: Guilford Press.

Wilbur, R. C. (2008). St.Louis blues: Tax credits down and out in Missouri. Education Next, 8(1), 30-37. Retrieved from Education Full Text (H.W. Wilson).

Williams, J. M., \& Nierengarten, G. (2011). Recommendations from the north star state: Rural administrators speak out. Rural Educator, 33(1), 15-24. Retrieved from Education Research Complete.

Wolf, P. J. (2009). Lost opportunities. Education Next, 9(4), 48-56. Retrieved from Education Full Text (H.W. Wilson). 
SOCIAL ENTERPRISE AND CHRISTIAN SCHOOL FINANCE

Yunus, M., \& Weber, K. (2007). Creating a world without poverty: Social business and the future of capitalism. New York, NY: PublicAffairs.

Zandstra, A. M. (2012). Mission statements of Christian elementary schools in the United States and the Netherlands. Journal of Research on Christian Education, 21(2), 116-131. Retrieved from ERIC. 


\section{APPENDIX A}

\section{SURVEY INSTRUMENT}

This appendix contains a copy of the survey instrument used in this study. The original instrument was printed on the front and back of a single page. Due to differences in margins and layout that pagination is not fully reflected here. All other elements have been kept in place as on the original survey.

Social Enterprise School Survey

\section{Part 1: Current Involvement}

Instructions: Please rate your school's involvement with each activity using the scale below. Circle the number that best matches your school's current level of participation in this activity.

$1=$ No involvement $\quad 3=$ Modest Involvement $\quad 5=$ This activity has become a part of our school culture.

1. Sponsorships -- School materials, facilities, or events have corporate $\begin{array}{lllll}1 & 2 & 3 & 4 & 5\end{array}$ sponsors who provide the school with either financial income or inkind services in exchange for being named as a sponsor.

2. Exclusive agreements -- One or more csompanies is allowed exclusive $\begin{array}{lllll}1 & 2 & 3 & 4 & 5\end{array}$ marketing rights for their category of product or service within your school building, at school events, or in school materials in exchange 


\begin{tabular}{|c|c|c|c|c|}
\hline for providing the school with financial income or in-kind services. & & & & \\
\hline $\begin{array}{l}\text { 3. Incentive Programs -- Students are encouraged to participate in } \\
\text { corporately sponsored educational incentive programs. }\end{array}$ & 12 & 3 & 4 & 5 \\
\hline $\begin{array}{l}\text { 4. Appropriation of Space (commercial) -- Space is rented out within } \\
\text { your school building for commercial activity. }\end{array}$ & 12 & 3 & 4 & 5 \\
\hline $\begin{array}{l}\text { 5. Appropriation of Space (Non-commercial) -- Space is rented out } \\
\text { within your school building for non-commercial activity. }\end{array}$ & 12 & 3 & 4 & 5 \\
\hline $\begin{array}{l}\text { 6. Electronic Marketing -- Commercial ventures are allowed to market } \\
\text { to students or families through use of the school's e-mail list, } \\
\text { website, or other electronic media (including Channel One). }\end{array}$ & 12 & 3 & 4 & 5 \\
\hline $\begin{array}{l}\text { 7. Fund Raisers -- Students are encouraged to participate in sales of } \\
\text { goods or services with a portion of the profit providing a financial } \\
\text { benefit to the school or funding specific activities. }\end{array}$ & 12 & 3 & 4 & 5 \\
\hline $\begin{array}{l}\text { 8. Privatization -- Specific educational functions of the school have } \\
\text { been outsourced to a private company. }\end{array}$ & 12 & 3 & 4 & 5 \\
\hline $\begin{array}{l}\text { 9. Social Enterprise } 1 \text {-- The school partners with or runs an ongoing } \\
\text { commercial venture whose primary purpose is to provide funds for } \\
\text { the school. An example would be a thrift store operated to fund } \\
\text { scholarships for deserving students. }\end{array}$ & 12 & 3 & 4 & 5 \\
\hline $\begin{array}{l}\text { 10. Social Enterprise } 2 \text {-- The school produces materials which it sells at a } \\
\text { profit to other entities. }\end{array}$ & 12 & 3 & 4 & 5 \\
\hline $\begin{array}{l}\text { 11. Social Enterprise } 3 \text {-- The school provides training opportunities } \\
\text { beyond those offered to the primary student body for a profit. }\end{array}$ & 12 & 3 & 4 & 5 \\
\hline
\end{tabular}

Continue on Back Side

\section{Part 2: Scenarios}

Instructions: Each scenario below provides a representative sample of one way in which a developing field known as "social enterprise" in the non-profit academic literature can be applied to a Christian school environment. Please indicate on the scale below your level of support for participating in this type of activity as a way of raising money to support your school's mission as well as the degree of interest you expect your board of directors as a group would express.

1= Strongly opposed $3=$ Somewhat interested in considering, but would want to do some research $5=$ This sounds very exciting and I would be very interested. 


\begin{tabular}{|c|c|c|}
\hline Scenario: You have the opportunity to ... & Your Interest & $\begin{array}{l}\text { Anticipated } \\
\text { Board Interest }\end{array}$ \\
\hline $\begin{array}{l}\text { 1. start a thrift store with a high percentage of the profit } \\
\text { benefiting the school }\end{array}$ & $\begin{array}{lllll}1 & 2 & 3 & 4 & 5\end{array}$ & 12345 \\
\hline $\begin{array}{l}\text { 2. provide supplemental services which complement } \\
\text { your school's mission to your existing families such as } \\
\text { child care or tutoring. }\end{array}$ & $\begin{array}{lllll}1 & 2 & 3 & 4 & 5\end{array}$ & 12345 \\
\hline $\begin{array}{l}\text { 3. provide services similar to those named in scenario } 2 \\
\text { to an audience that includes families not enrolled at } \\
\text { your school some of whom may not come from a } \\
\text { Christian background. }\end{array}$ & $\begin{array}{lllll}12 & 2 & 4 & 5\end{array}$ & 12345 \\
\hline $\begin{array}{l}\text { 4. offer classes to adults from local churches such as } \\
\text { training for Sunday school teachers by providing } \\
\text { supplemental contracts to your existing faculty } \\
\text { members to serve as instructors. }\end{array}$ & 12345 & 12345 \\
\hline $\begin{array}{l}\text { 5. use your existing faculty (with the possible addition of } \\
\text { a few new hires if all goes well) to create curriculum } \\
\text { materials to be used by local churches and / or other } \\
\text { Christian schools. }\end{array}$ & $\begin{array}{lllll}12 & 2 & 4 & 5\end{array}$ & $\begin{array}{lllll}1 & 2 & 3 & 4 & 5\end{array}$ \\
\hline $\begin{array}{l}\text { 6. rent out space within your school building during after } \\
\text { school or weekend hours for commercial activity that } \\
\text { does not directly complement the school's mission, } \\
\text { but is not morally objectionable. }\end{array}$ & $\begin{array}{lllll}1 & 2 & 3 & 4 & 5\end{array}$ & $\begin{array}{lllll}1 & 2 & 3 & 4 & 5\end{array}$ \\
\hline $\begin{array}{l}\text { 7. rent out extra space in the school during school hours } \\
\text { as office space. }\end{array}$ & $\begin{array}{lllll}1 & 2 & 3 & 4 & 5\end{array}$ & 12345 \\
\hline $\begin{array}{l}\text { 8. promote specific products, services, or retailers } \\
\text { (online or offline) to school families }\end{array}$ & $\begin{array}{lllll}1 & 2 & 3 & 4 & 5\end{array}$ & 12345 \\
\hline $\begin{array}{l}\text { 9. seek out corporate sponsorships of educational } \\
\text { facilities, materials, or events }\end{array}$ & $\begin{array}{lllll}1 & 2 & 3 & 4 & 5\end{array}$ & $\begin{array}{lllll}1 & 2 & 3 & 4 & 5\end{array}$ \\
\hline
\end{tabular}

Thank You! 